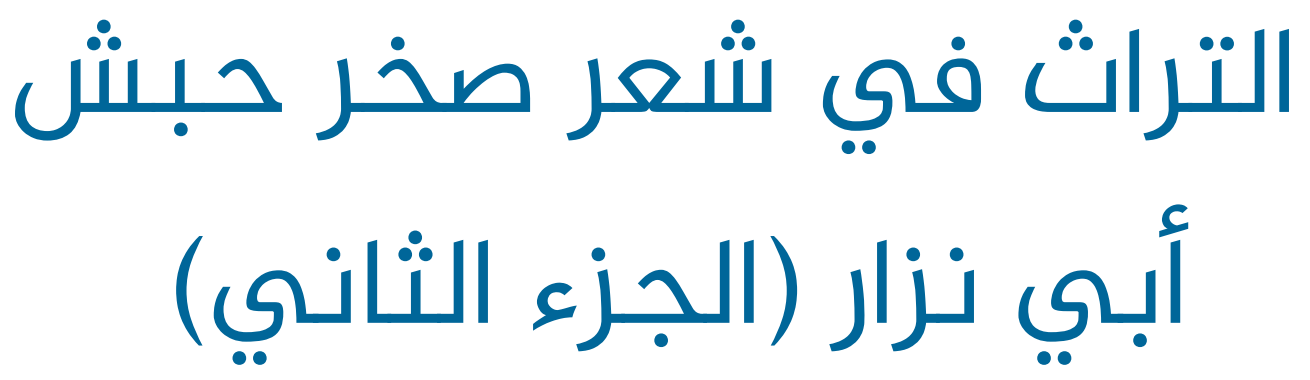

$$
\begin{gathered}
\text { جادعة القدس ساري الديك الدفتوحة- فلسطين } \\
\text { nadishameem@yahoo.com }
\end{gathered}
$$




$$
\text { المجلة الدولية للدراسـات اللغوية والأدبية العربية }
$$

International Journal for Arabic Linguistics and Literature Studies (JALLS)

\title{
التراث في شعر صخر حبش أبي نزار (الجزء الثاني)
}

\author{
نادي ساري الديك \\ جامعة القدس المفتوحة- فلسطين \\ nadishameem@yahoo.com
}

DOI: https://doi.org/10.31559/JALLS2021.3.2.1 2021/4/8 2021/3/2 مراجعة البحث: 2021/3/20 قبول البحث البحث: 201/20

الملخخص:

التراث مفردة لها وقعها ودلالاتها في نفوس المنشئين للأدب، والمتلقين له على حدّ سواء، ما جعل الشعراء المعاصرين

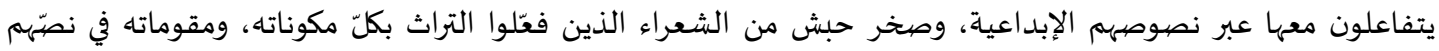

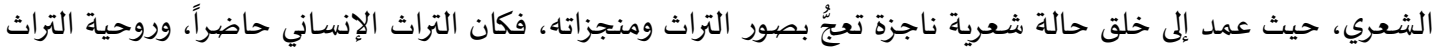

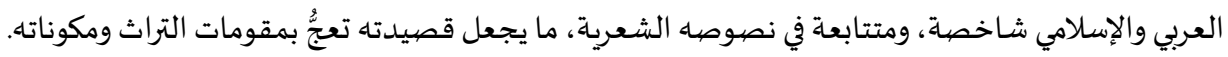

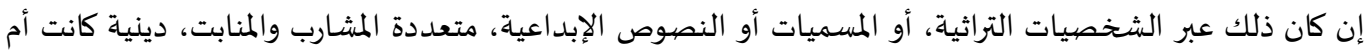

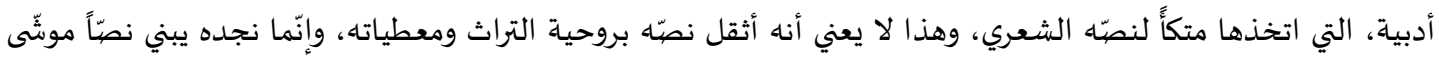

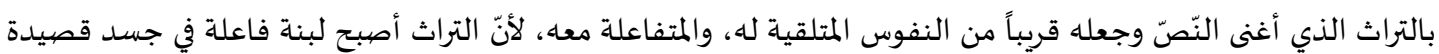
صخر حبش الشعرية. الكلمات المفتاحية: نصوص شعرية؛ تراث؛ أدب.

ثقافة الشعراء متباينة على مر العصور، إلّا أن بعضهم يلتقون مع غيرهم عبر سياقات ثقافية وفكرية متعددة، تجمعهم أو

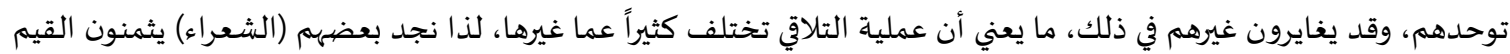

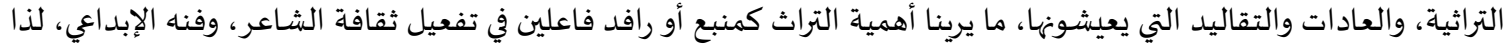

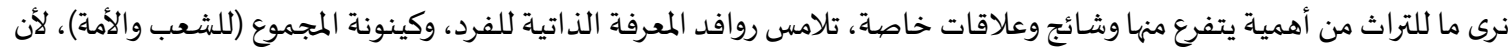

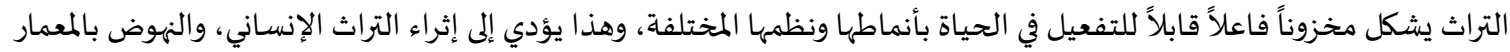

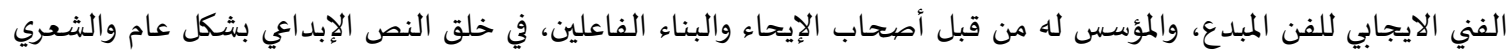
بشكل خاص.

لذا نرى نص صخر أبي نزار الشعري يعج بالقيم التراثية والثقافية، التي ارتكز عليها، وفعلها في معماريّة نصيّه الإبداعي،لان كثياً الثياً

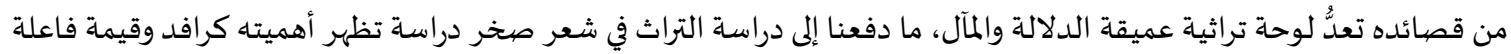

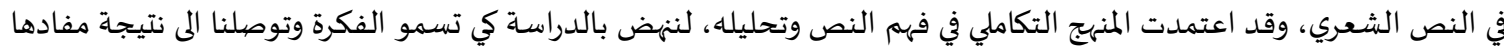

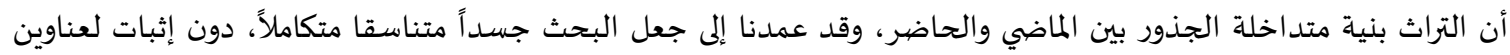
فرعية، ومن ثم دونا المصادر والمراجع التي أعانت الباحث في توثيق دراسته وتفعيلها.

* نُشر الجزء الأول من البحث في المجلد الثالث، العدد الأول 2021 * 


\section{تداخل الموروث التاريخي والديني:}

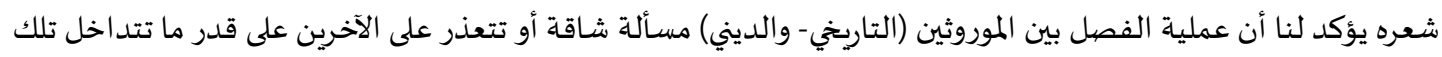

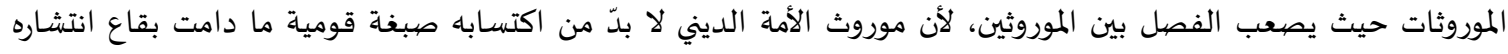

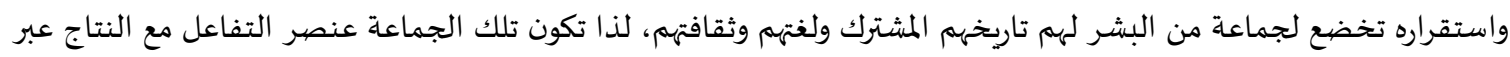
هذه الأزمنة.

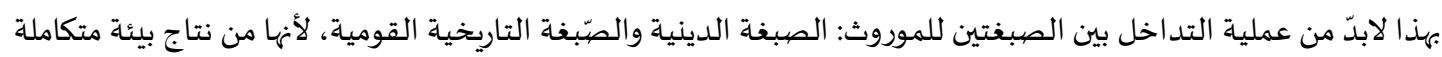

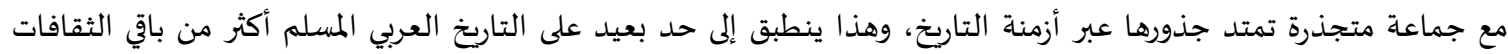

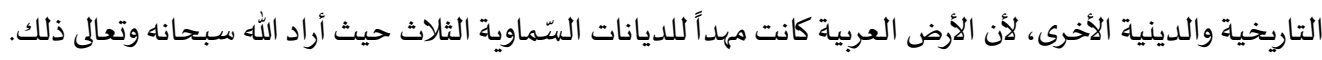

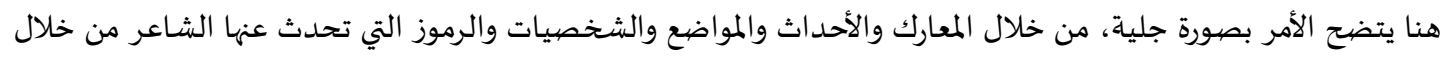

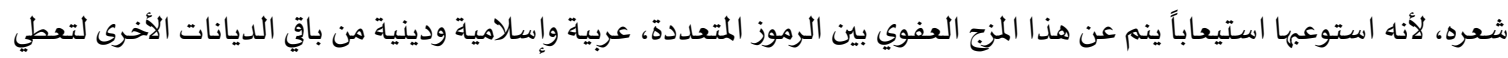

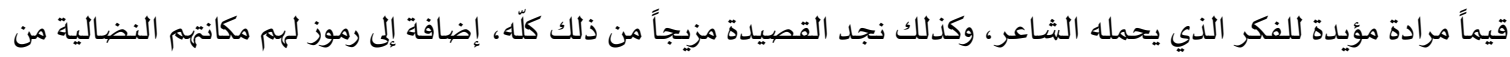

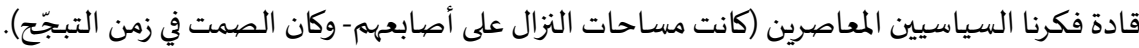

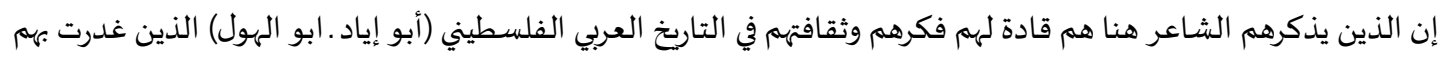

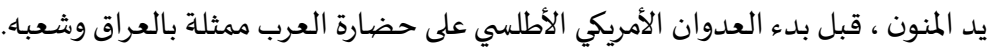

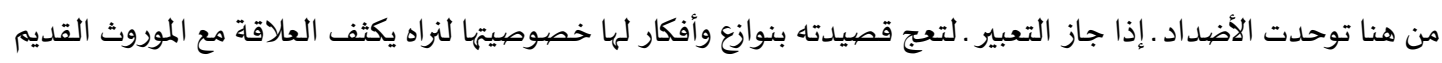

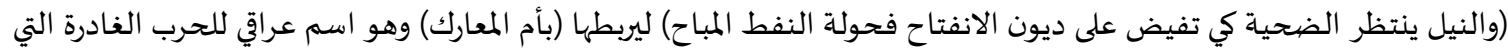

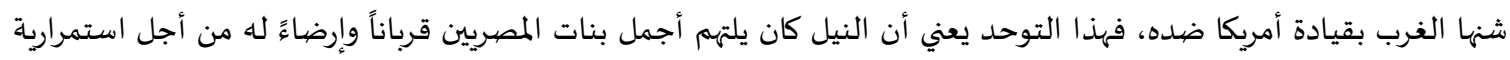

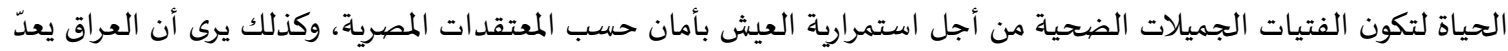

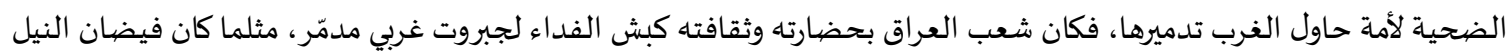

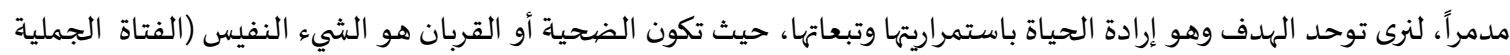
سابقاً. حضارة العراق وشعبه لاحقاً)

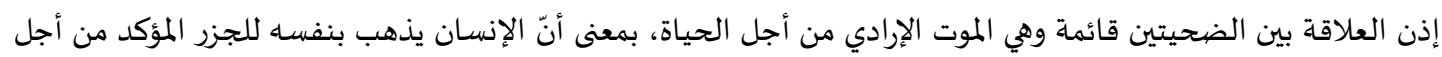

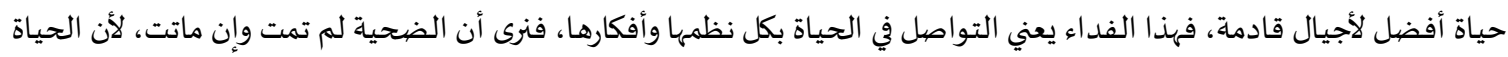

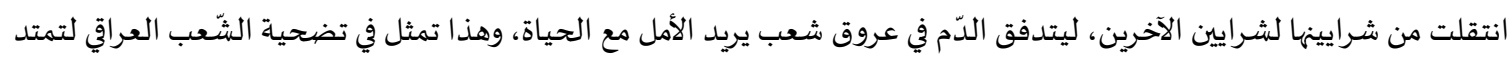

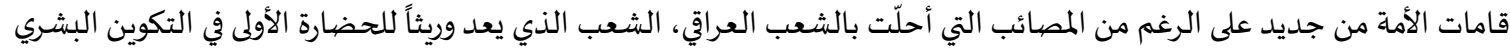

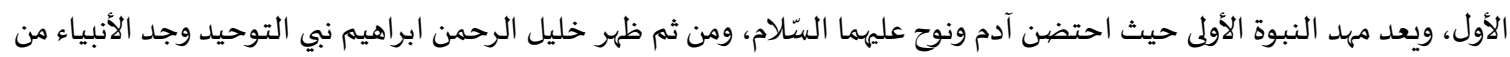

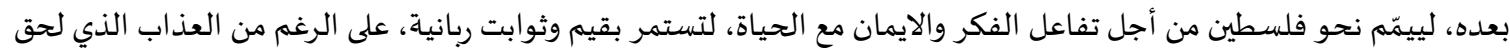

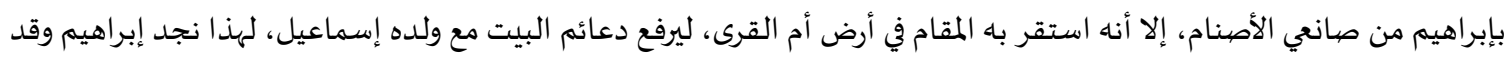

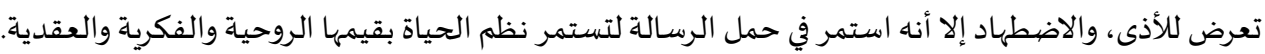

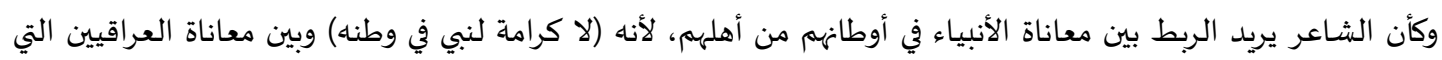

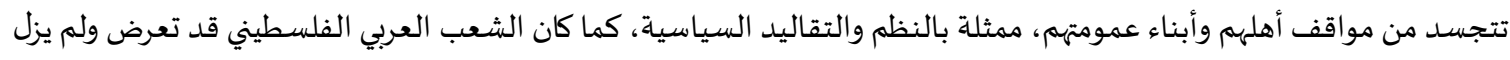

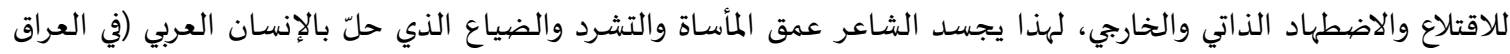

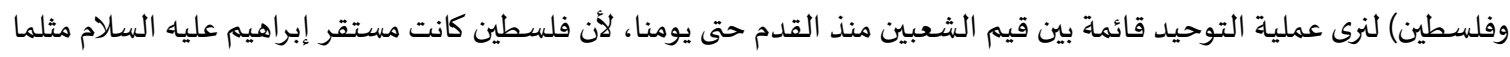

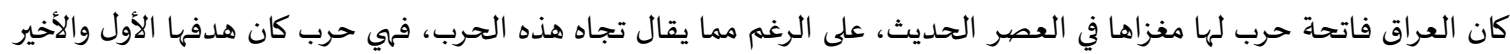

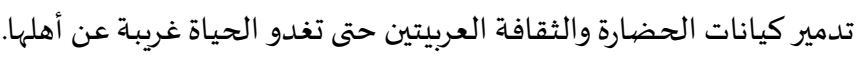

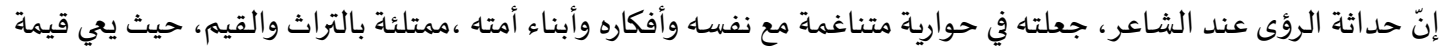

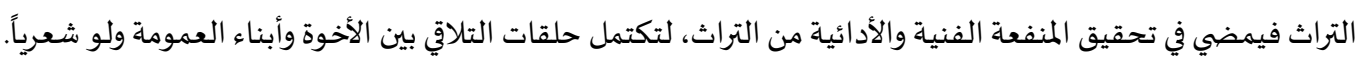

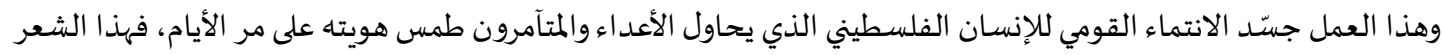

يخلق ميزة ذات فاعلية في الوقت نفسهاء للمجتمع والقضية لانية معاً.

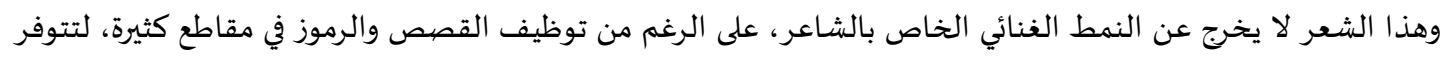

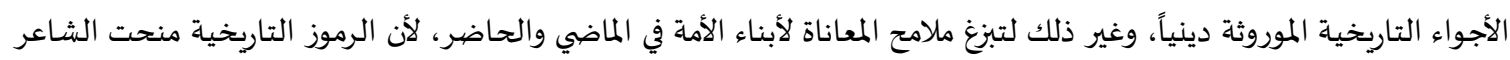


زخماً روحياً مطلوباً في بنائه الشعري.

فعلى الرغم من تداخل الرموز (عتيقة وحديثة) دينية ووثنية، فإن كثيراً من شعر الشاعر أقرب ما يكون إلى توظيف التراث

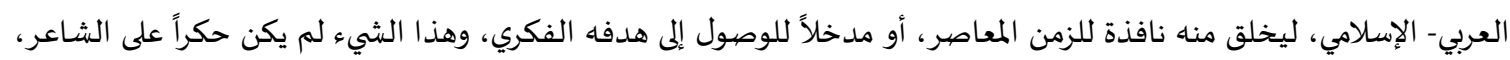
وإنما نجد نماذج فاعلة عند شعراء كثيرين من العرب الفلسطينيين، إلا أن صخراً يبقى حريصاً على توظيف الموروث، هودئ وعلى اختيار

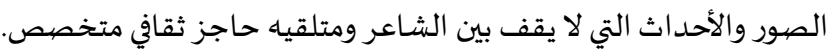

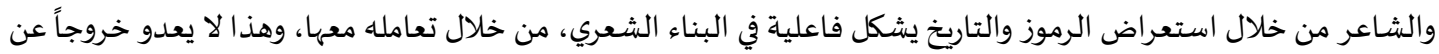

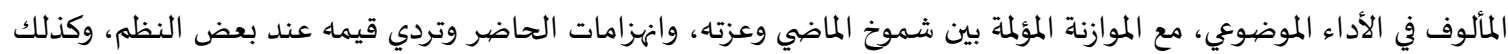

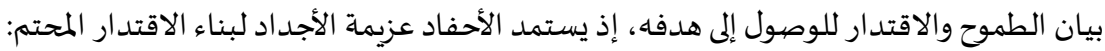

رئتانِ من وجنْ

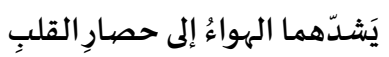

بينَ دمٍ يسيلُ على دمٍ

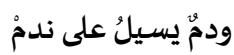

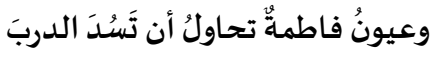

في وجـِ العدمْ

شَخَصَتْ عيونُ الرِِِ وهي ترى

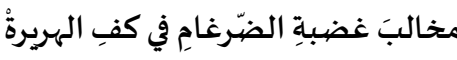

وهي تجمحُ بين اسرابِ القطظٌ

وتصبَّ غيظَ النفطِ فوقَ النارِ

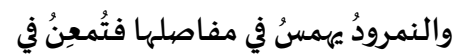

الغَلطُ..

ويدوسُ ابراهيمُ وكرَالجاهليةً

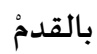

•.ورحيقُ فاطمةٍ يفيضُ على حقولِ بـ

النفطِ شهداً، والجراحُ تحيطُ بالقلب

المحاصيز

والهواءُ المباء

سيفن

وذاكرةُ الخيانةِ في الوسطُ

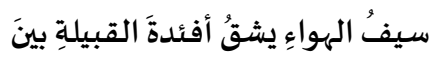

من ركعوا على ركبِ الخُضِوعِ وبينَ من

ركبوا صهيلَ المجدِد

والرئتانِ ساريتانِ

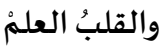

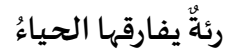

وترددُ الأخرى مع الزفراتِ أنفاسَ

القسمْ..

وأغنيةُ الحجارة صدرُفاطمـة التي

فضحتَّ حدودَ الجاهليةِ واستردتُ

جُرحها من كل قافيةٍ تصبّ الشهَد في

كأسِ الرياءْ

في المِرَبِدِ ارتفعتْ مآذنَ من عيونِ 


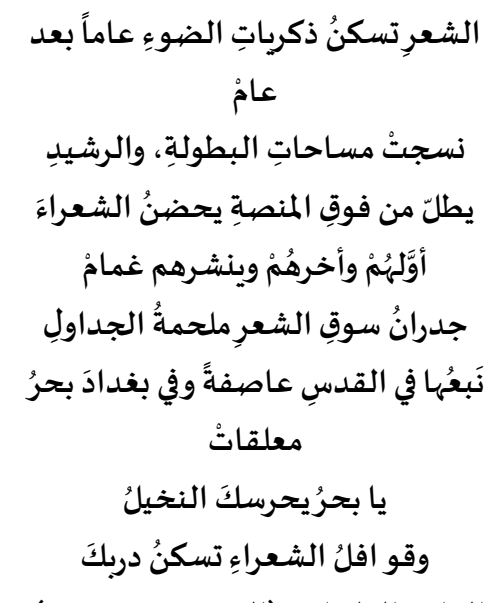

لقد ظلل الموروث صاحب بصمات واضحة على رذاذ قصائده ونداه، في هذه الحقبة الزمنية التي تعج بمضامين متعددة الجوانب المبادي ومتنوعة الميول والجذور، حيث تداخلت مفرداته المنسوجة مع مفردات الموروث القومي الذي تعيشه بعض الأجداد العظام، لتتواصل

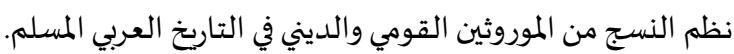

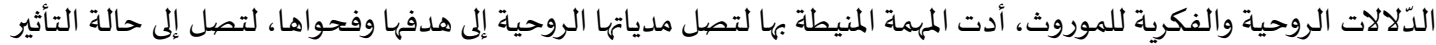

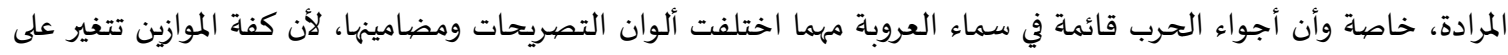

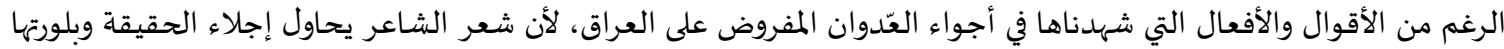

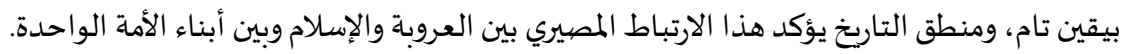

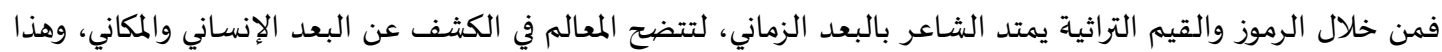

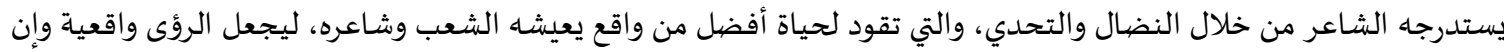

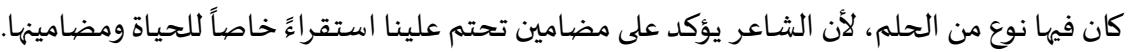

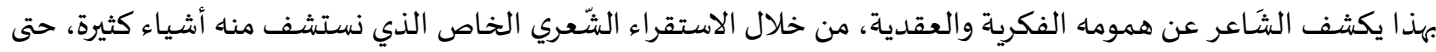

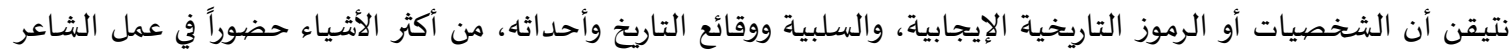

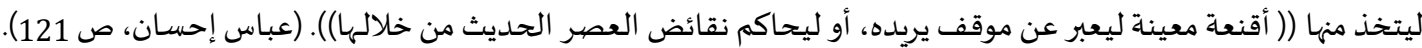

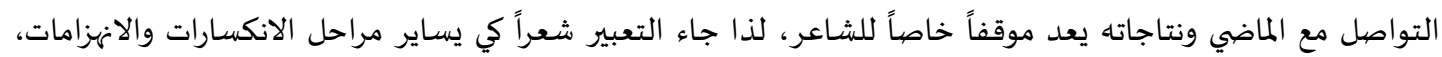

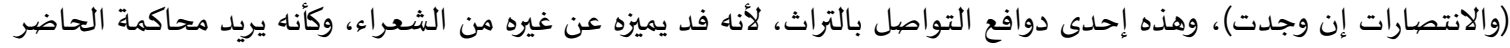

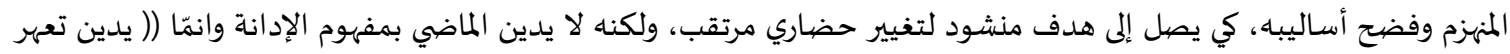

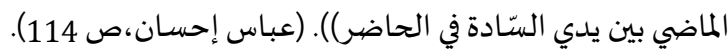

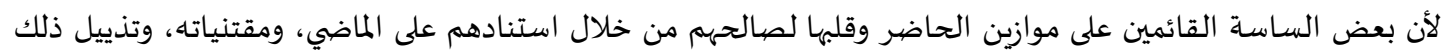

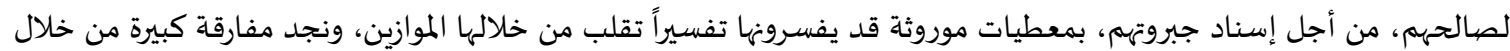
موازين الحياة وقيمها. إن غوص الشّاعر في التاريخ ورموزه بأبعاده المختلفة، يجعلنا نرى خريطة لمعجم شعري مليء بالتراث الزاخر، والإيحاءات والرموز

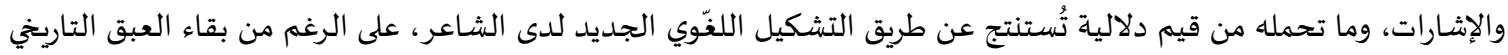

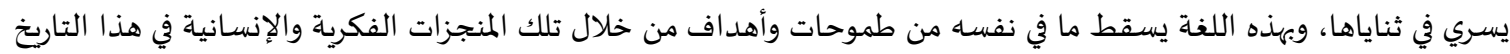

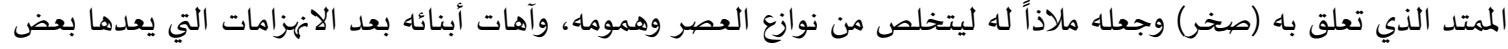
النفعيين انتصارات وهي علائق وهمية ليس إلا. بهذا تظهر مسميات لشخصيات دينية وتراثية وفكرية من خلال نتاجه الشعري، ويؤكد على أدراجها بوضيوح دائم، وبمغزى مؤكد

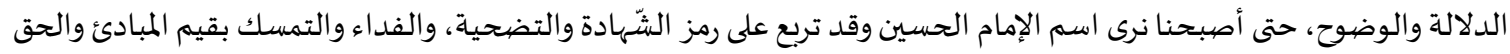

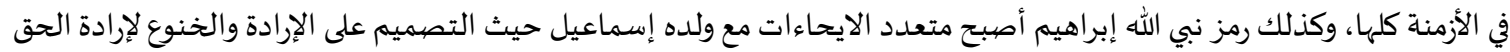

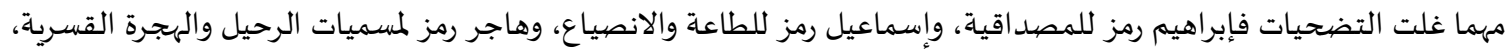




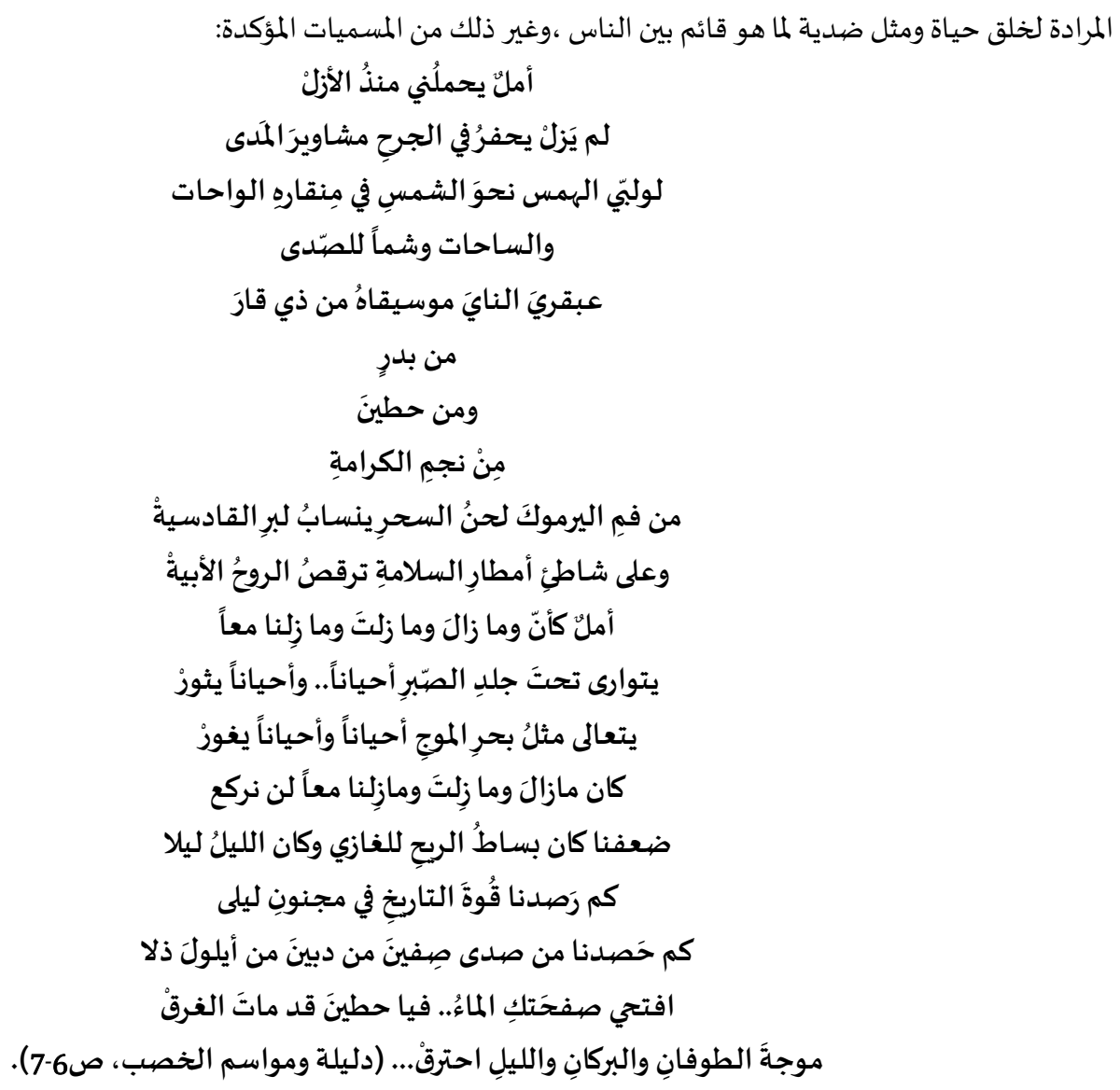

بهذا النمط يتحول الشاعر إلى رموز متعددة في منابعها وأيامها، ويجعل الفردية في البطولة مدخلاً للبطولة التاريخية المشتركة،

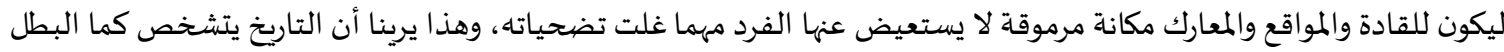

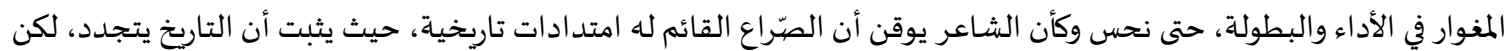
بتباين الصيغ والمعادلة، إلا أن زخم البطولة يتجدد.

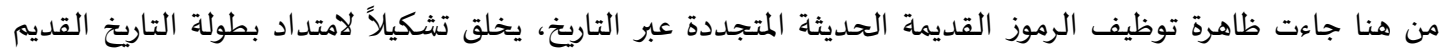
لينبعث الأمر، ويصبح حافزاً لما سيأتي من الزمن القادم، بمعنى أن الشاعر أقام معادلته على أساس استحضيار التاريخ القديم، لنراه

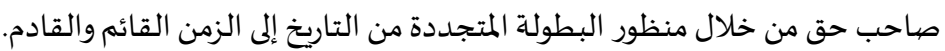

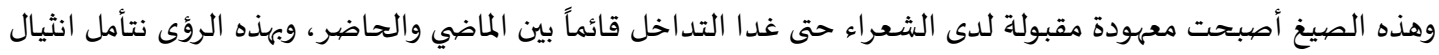

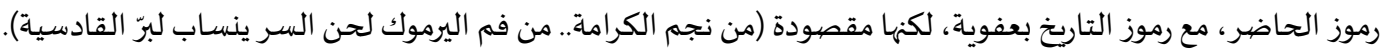

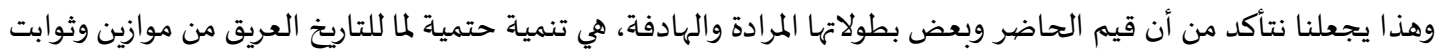
واندفاعات بنًاءة.

فعندما يتغنى صخر، بأمجاد المواقع والرموز الثورية التي انبثقت نتيجة لحتمية مؤكدة صوب النصري، نراه هنا يصّر على تحويل زخم البطولة إلى مستويات التاريخ، ورحابه لمنحها صفة الاقتدار، وانبثاقه من أجل استقرار خواطر النفوس المتلقية لنتيجة الحدثث في وي جم.

في هذا العمل نجد الشّاعر وقد سكن وعي التاريخ العربي المنتمي إليه قلباً وقالباً، فكراً وعقيدة، مع فاعلية كبيرة للحاضر الذي الذيا

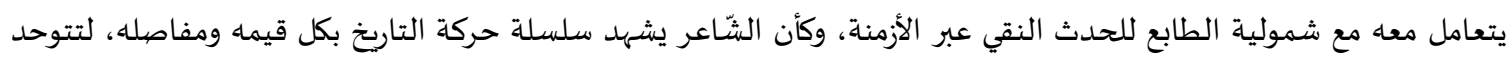

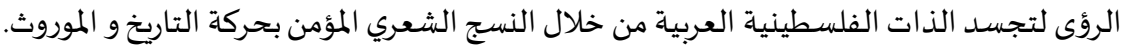

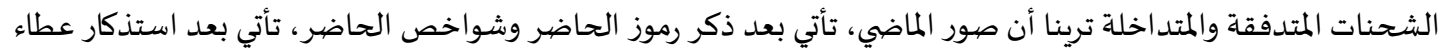

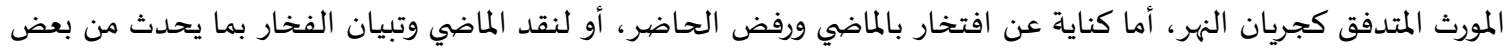

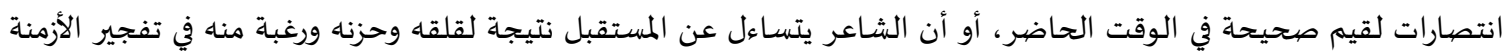


المتخلخلة، لرسم أشكال جديدة لأزمان تتجدد مع الزمن المستمر، وهذه الرموز قد تحتمل اكثر من معنى للمقدرة التحليلية لدى الملمقي والمتلقي.

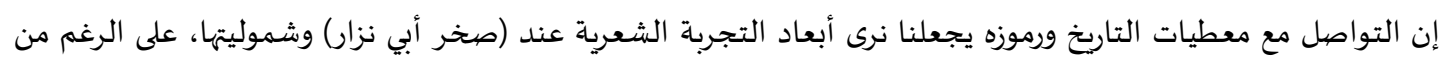

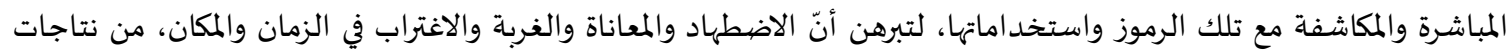

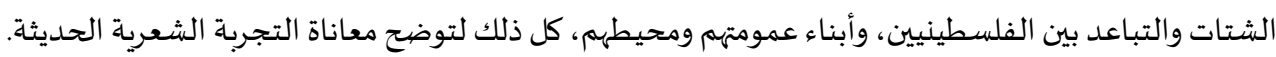

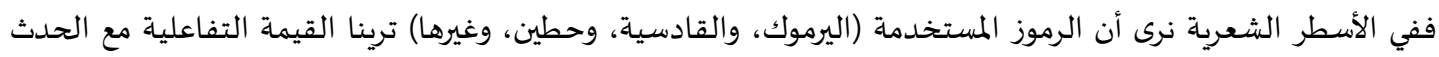

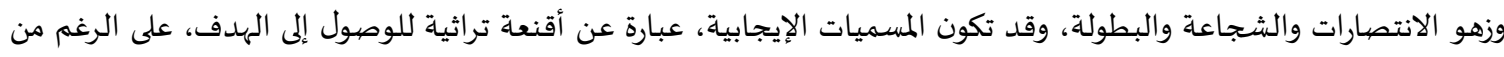

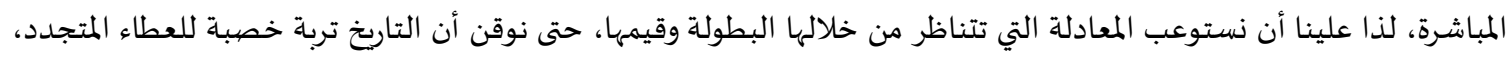

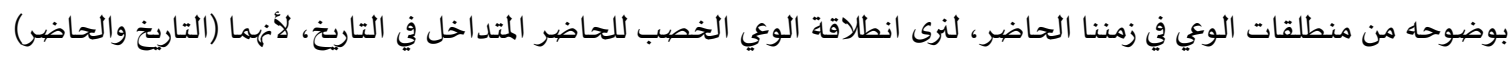

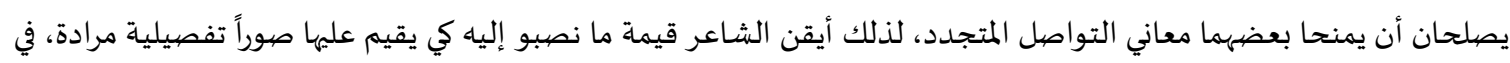
قصيائده وأسطره الشعرية، ليتجسد عطاء الأجداد من خلال قيم الأحفاد البطولية: وحينَ يكونُ، ويمتدُ فينا الوطنْ

$$
\text { يصيز كبيراً }
$$$$
\text { وتسبحُ فيهِ المشاويرِ }
$$

من ضفتيهِ.. إلى قلبِهِ ترحلن

وحينَ يكونُ أسيراً تذوبُ عليهِ الحكايه ترجيا

$$
\text { وفيه المنى تجمَّل }
$$

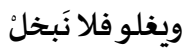

وحينَ يعانقهُ العاشقونَ وَلَّلَ

على جبل النارٍ

تمتدُ اذرعُ روما توان

وو ائلَ فيها

فلسطينُ تمشي تمئر

يقطعُ حبلَ المسافاتِ

يعرفُهُ الباحثُونَ عن الشمسي المساتِ

والمتعبونَ.. الجياعَ.. العر ايا. ويمشي الئي

وبيروتُ تنكرةُوهوفيها

وتخشاهُكل العواصيمِ

من يستطيعَ احتضان فلسطينَ غيرِفِلسطينَ

وتُزهرُفي طولكرمَ المواويلَ

محمودُ عادْ

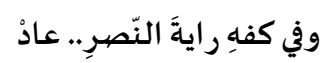

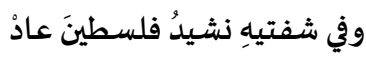

وباريسَ ما ودعتهُه..

بكت يَومَ غادرها والبلادُ التي ضَيعتَّ أهلها

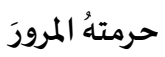

من البِّ

والبحرِ

والجوِ

لكنهُ عادَ يحملُ اسما جديداً... (شهادات للجرح المقاتل ،ص 37-38). 
التعامل مع الرموز المعاصرة (وائل زعيتر، ومحمود الهمشري) وغيرهما يحّد أحد بواعث الهاجس المتمثل في الهم المتشعب لدى الشاعر ،لأن هذه الرموز لم تقتل وان قتلت كما يظن الأعداء (الذين اغتالوهم في روما وباريس، إلا أن الشاعر يجعلهما أحياء يرزقون

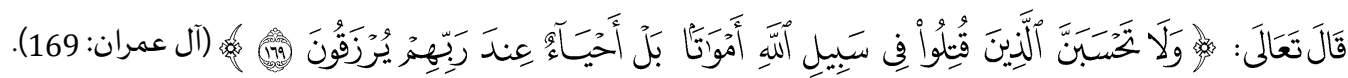
كما أكّد الله سبحانه وتعالى في قرآنه الكريم، وهذا يتمثل في الإيمان المطلق لدى الشـاعر من أن الخصوصية التي يتمتع بها الشهداء، لا توجد عند غيرهم من الناس، لما يتمتعون باه من قيم وثبات وعطاء متجدد، لأن هذه الرموز تحقق الانتصارات حتى لته

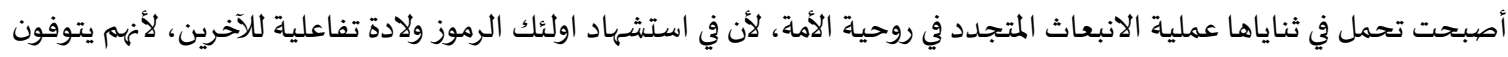
جسداً وتبقى أفكارهم وقيمهم فاعلة متجددة من جيل إلى جيل، وهذا يتجسـد في الغوص إلى أعماق الشاعر وذاته لتتجسـد البطولة، وتستمد عزمها من رموز معاصرين متفاعلين مع الحياة.

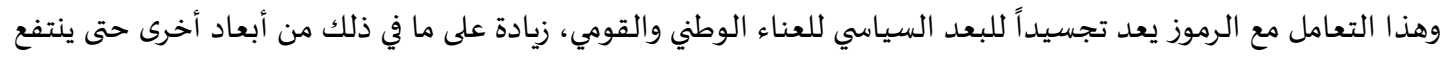
الشـاعر من هذه الرموز وقد (تراوح إسقاط الشعراء لهذه الرموز على القضايا المعاصرة، من مستوى ذكره فقط في ثنايا العمل الفني

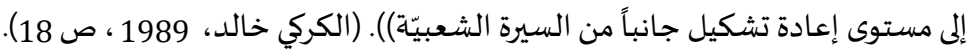
إن التوجاه صوب رموز الواقع، يعد خطوة فاعلة نحو الصواب اليقيني، لخلق حالة فاعلية في زمن تعج فيه الأفكار، وتتسارع

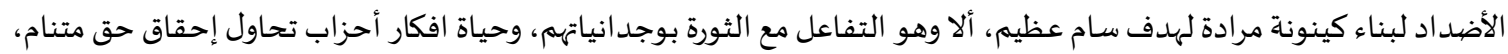
حيث الشاعر يعيش بفكره إلى جانب أفكار لأحزاب مختلفة، حيث الناس يبحثون عن ذواتهم من خلال الانخراط في الأحزاب بتنوع

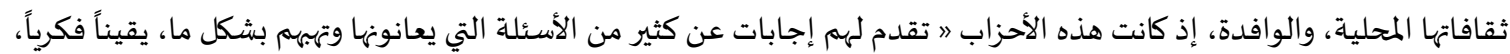

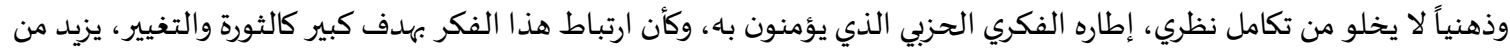

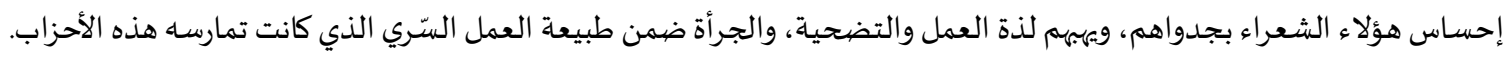

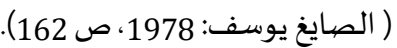
والشّّاعر (صخر) يرى في تلك الرموز المعاصرة (الثّوار، الثّهـاء، المفكرين) النموذج التطبيقي لتلك القيم والأفكار السياسية التي يؤمنون بها، من أجل هدف أسمى، وهو حرية الوطن وشمول المواطنة، لأن الشاعر هنا عُرف موقفه تجاه وطنها من خلال رموزه وحدد موقفه أيضاً من مغتصبي الحق والحرية وقتله الرموز والثوار، حيث ذلك أدّى إلى حالات الضعف واند وانكفاء الذات والتقوقع من هن

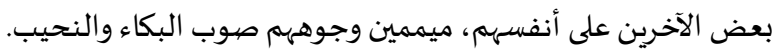
من هنا اتضحت الرؤى للجميع كل حسب مبتغاه وهدفه، ليغدو (الهمشري وزعيتر) رمزين متجددين عبر التاريخ المعاصر

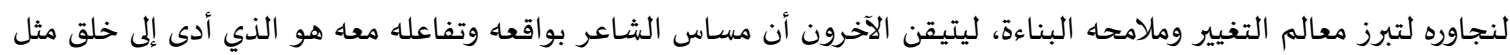

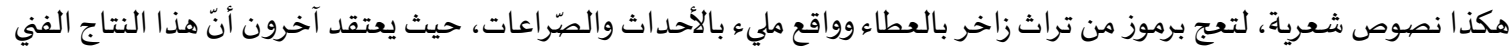

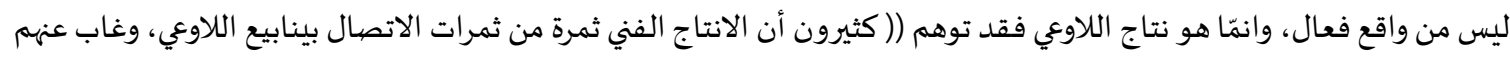

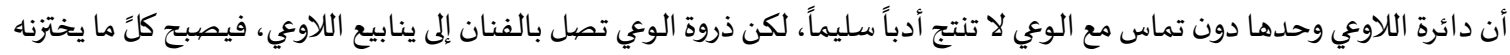

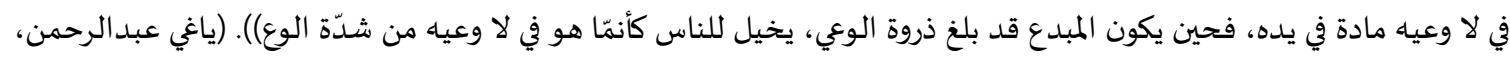

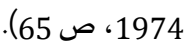
فالحياة التي يعيشها صخر، جعلته صاحب موقف يتطور بتطور الحركة الاجتماعية والسياسية، والتمازج القائم بين أبعاد القاعدة الإبداعية، (الموقف والوعي والموقع)، وتأثير الواقع قد يستشف من خلال بحث الشاعر عن رموزه، وتفاعله معها ليصل إلى الى

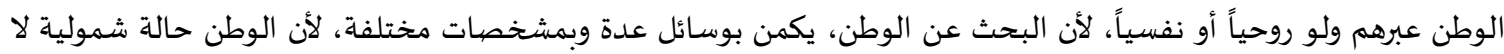

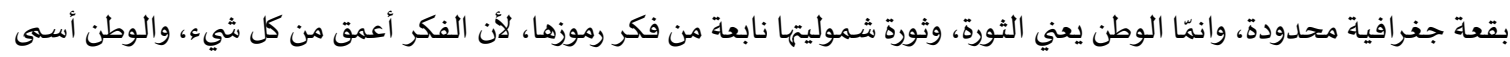

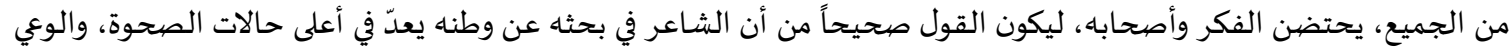

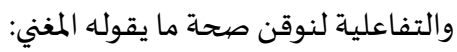

$$
\begin{aligned}
& \text { يقولُ المغني الذي عزفَ الشّعر } \\
& \text { إنَّ فلسـطينَ أرضُ القداسـة } \\
& \text { وأنّ على أرضهها للبراقِ مزاراً }
\end{aligned}
$$

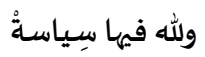

$$
\begin{aligned}
& \text { وشمسنُ الظهيرِة في القدسِ تُلقي }
\end{aligned}
$$




\author{
على صخرة الله روحَ السكونْ

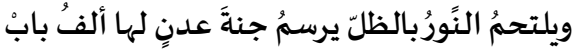

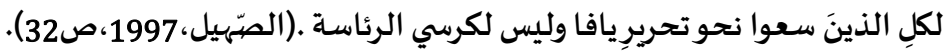

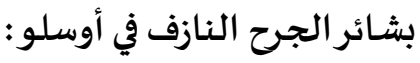

ما يعني ذلك، انّ الناس متفاوتون في علائقهم، وعلاقاتهم مع الأشياء، ففلسطين تجسّد رمز ألتفاعل مع الحياة، وينظر الشعراء

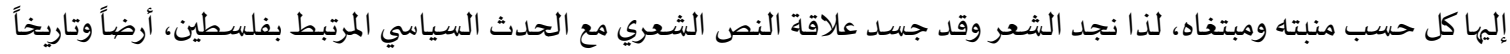

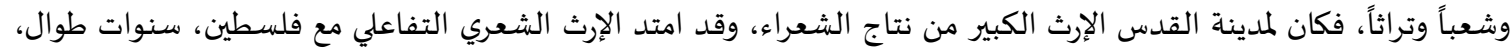

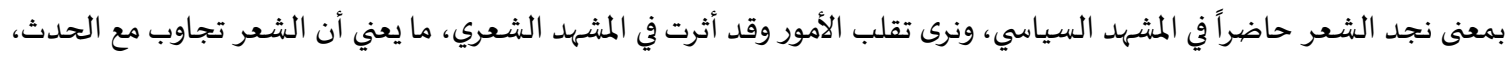

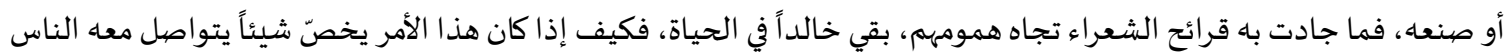

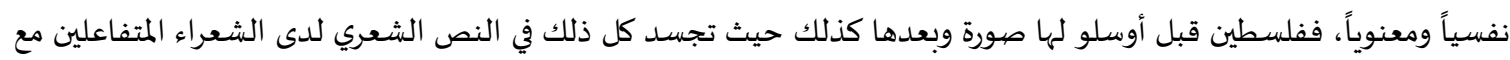

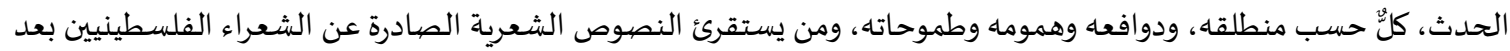

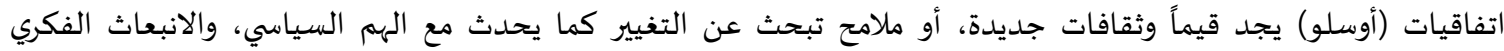

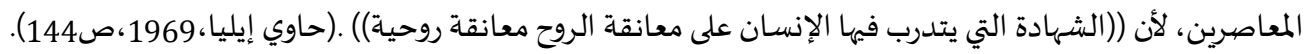

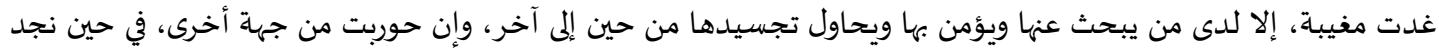

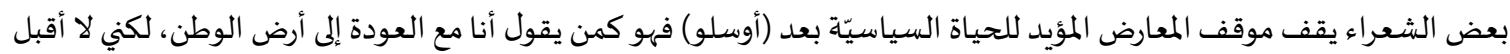

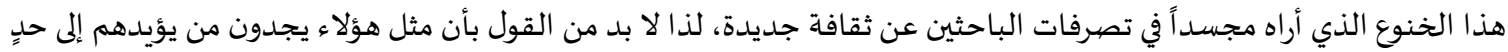

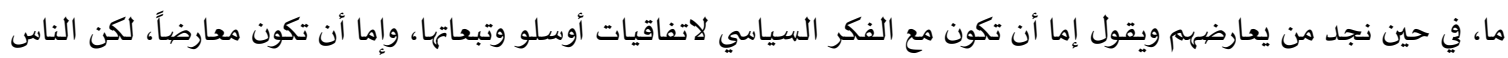

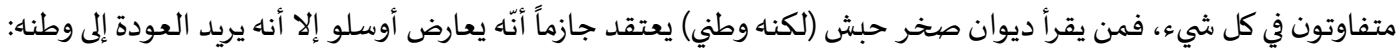

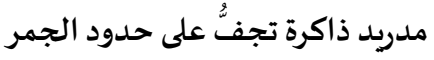
تخرج من مفاصلها حكايا الر اكعين بلا جباه

كانوا بدون رؤوسهم يتر اقصهون

وكان عنوان الوليمة

لاعناق بلاشفاه

الجمر خمروالكؤوس مظلة تسعى إلى مدريد

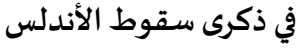

فلتفترس يا أهها الوحش أعناق الرعاة

فالأمر لا يعنيك الوحشي اعناق

لم تعد الأمور جميعها بيد الإله

القدس في مدربد قعرزجاجة فرغت من الوهم المحنط

تستجير من البكاء بالانتباه

سوريطوق غيمة الماضي وباسم الله

يذبح كل مئذنة تنادي للصهلاة

قسم وعهد لم يكن تحت اليد القران

بل شيخ يعود إلى صبباه

عزفت كؤوس الأشقياء مع الأشقاء النشيد

وكان رأس المعمدان يصب موسيقى النهاية في الحياة

الهرمن ظمأ تشقق ماؤه وصليب مغطسه يئن

إلى حدود الاشتباه

فالنهر حين تضيع جيهته يتوه 


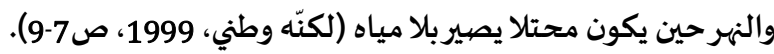

يقف الشاعر (صخر حبش) موقف الوسط تجاه الفلسفة السياسية التي تجتاح المنطقة، لذا نراه يمسك بأوليات خيط اللعبة ويحاول تعريتها للناس بعد نفسـ، فبعد العدوان على العراق عام 1991م، والبدء في سياسـة جديدة، ولو في مسماها، ألا وهي سياسـة

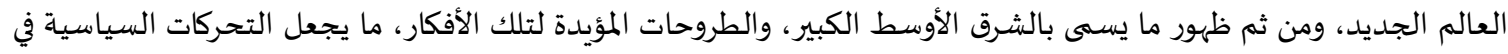

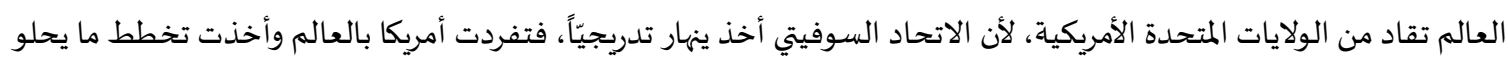

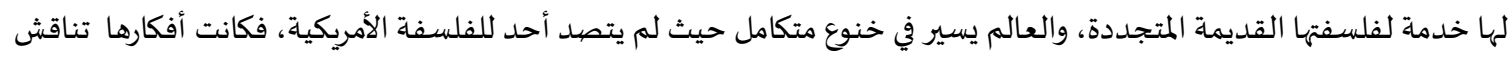

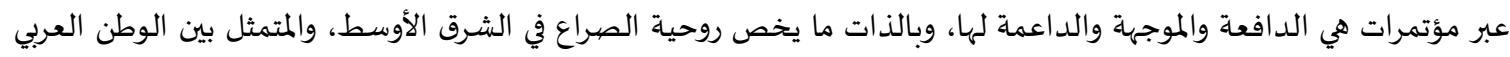

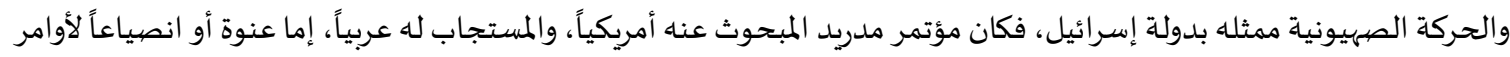

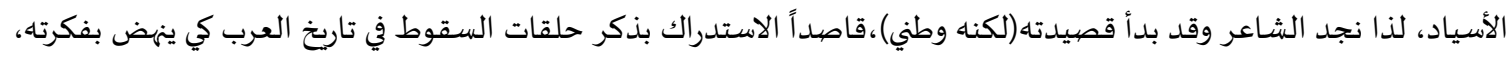
ويتكئ على شيء من التاريخ الذي تتكرر قيماه، لكن عبر عصيور متعددة، وإن كانت مضامينها واحدة، فما ذكر (مدريد) إلا للمقارنة بين

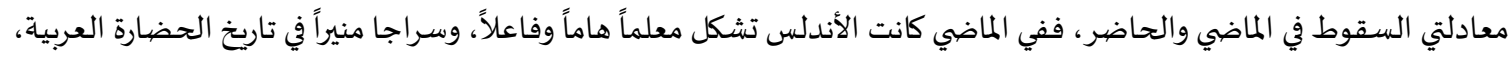

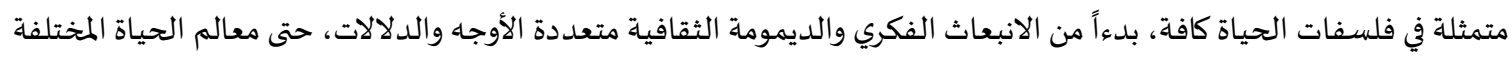

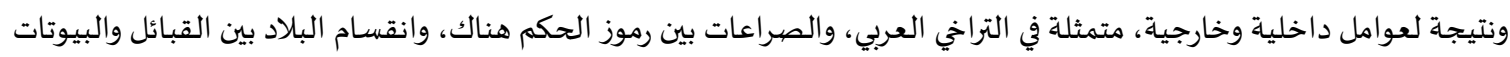

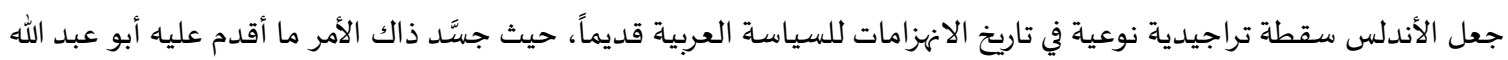
الصغير آخر ملوك بني الأحمر، في حقبة ملوك الطوائف من توقيع معاهدة الاستسلام والخنوع، أمام التحالف الأوروبي الصليبي،

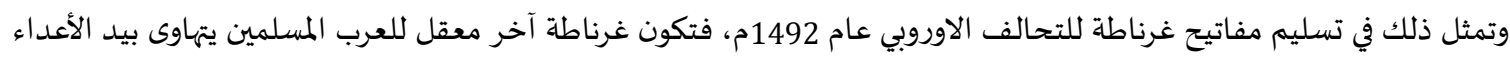

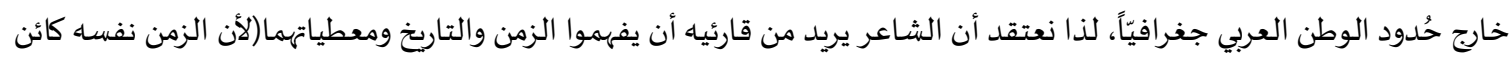

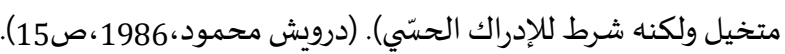

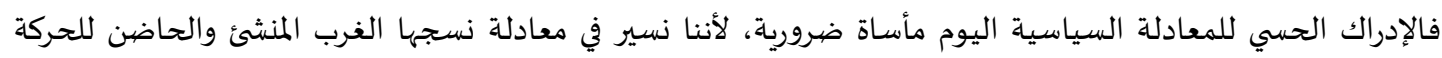

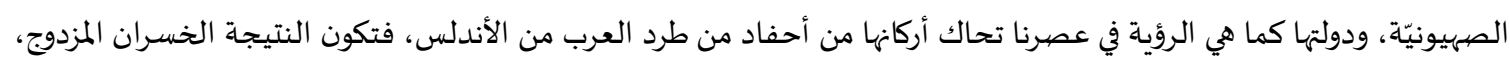

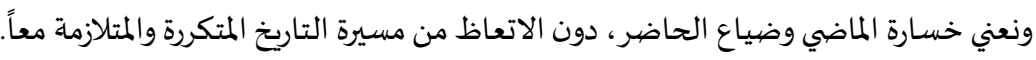

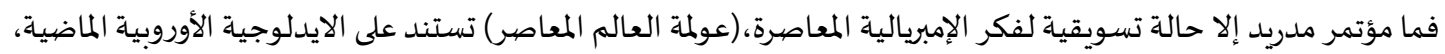

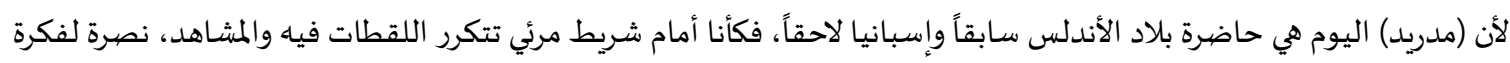

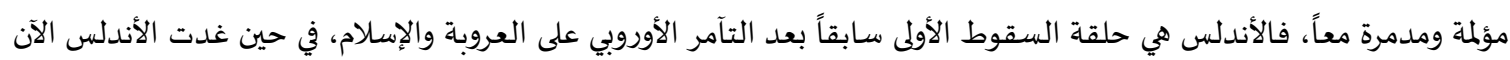

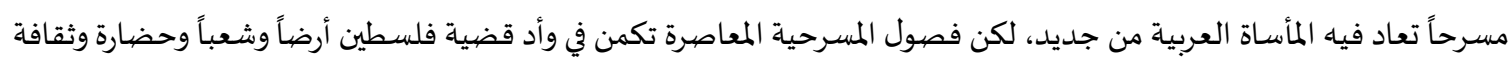

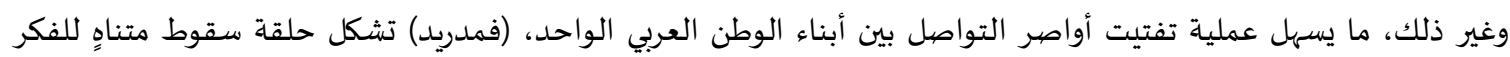

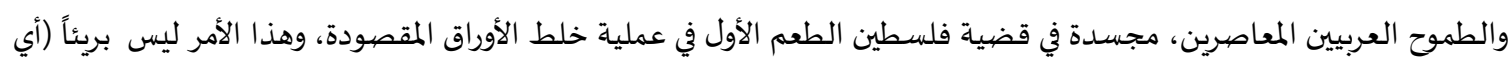

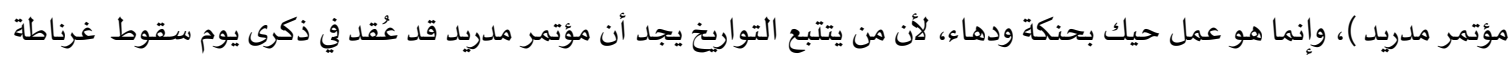

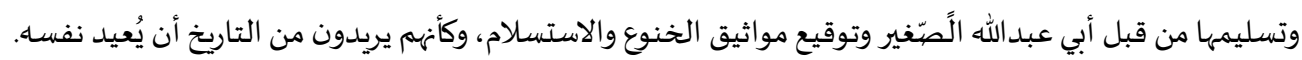

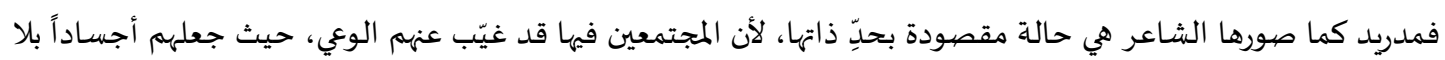

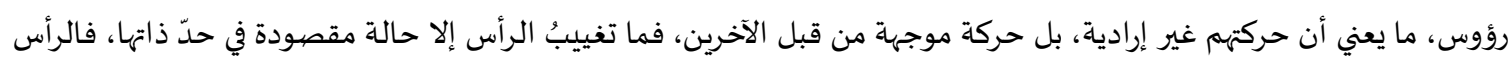

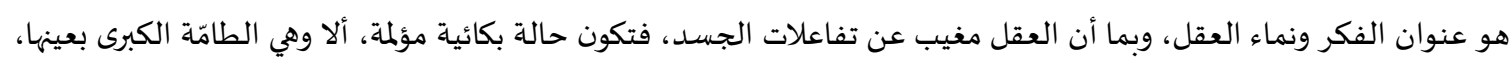

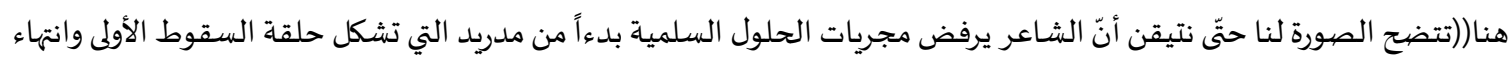

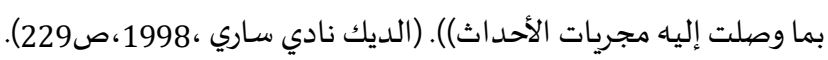

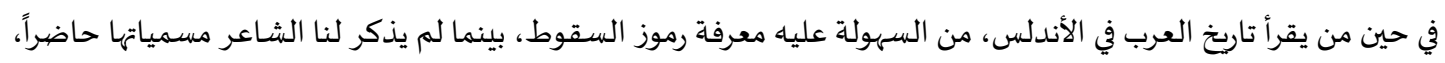

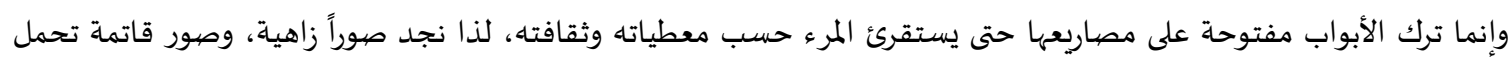

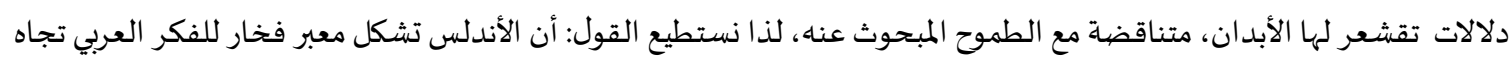

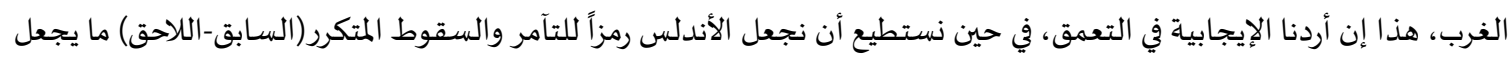

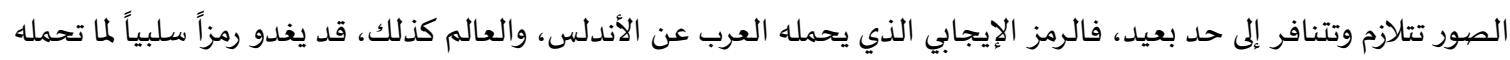

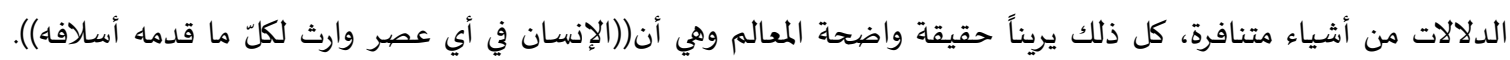

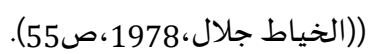




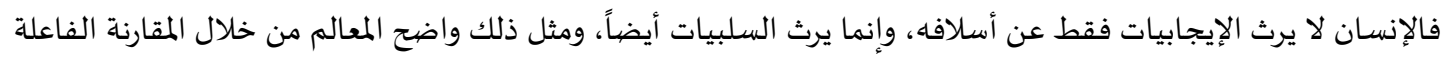

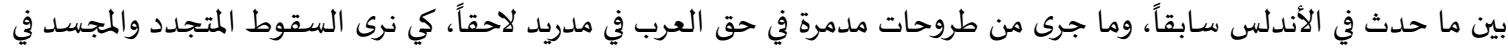

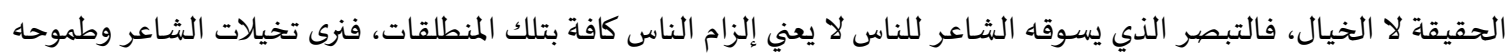

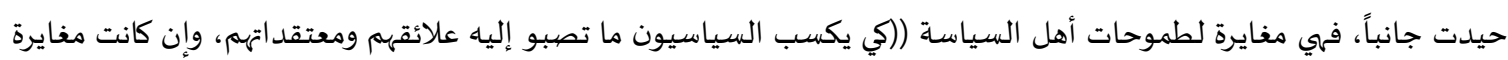

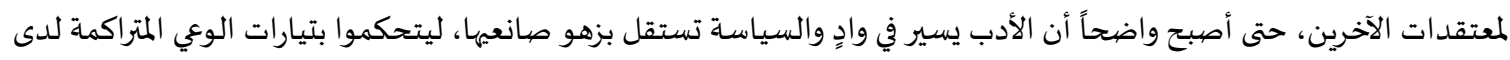

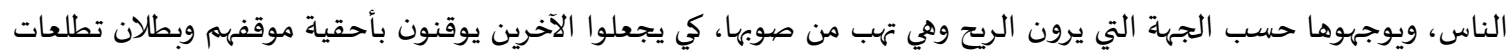

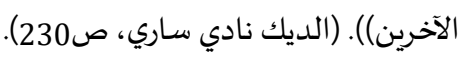

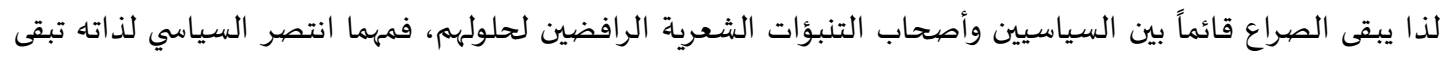

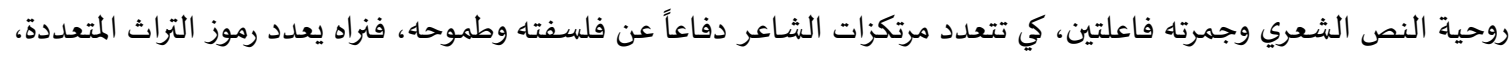

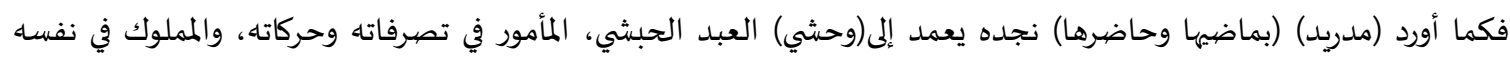

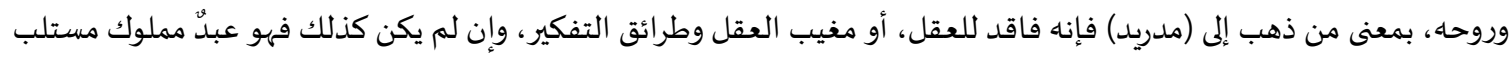

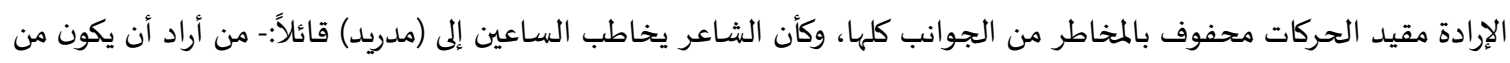

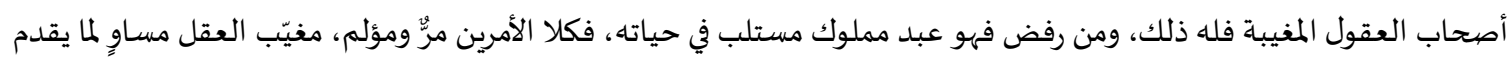

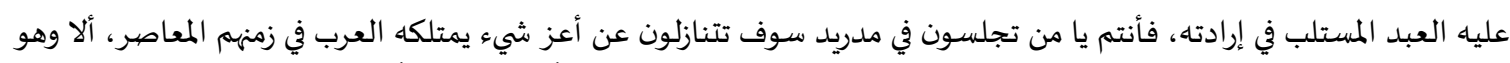

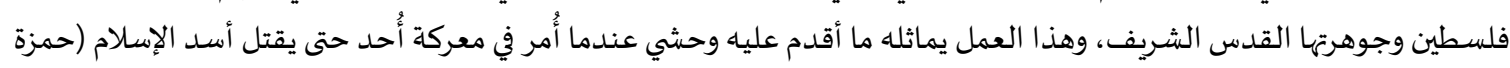

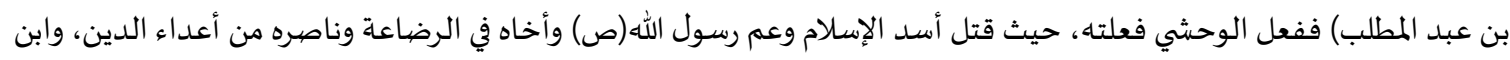

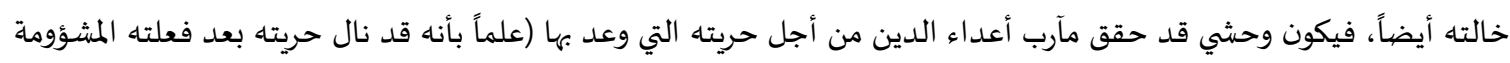

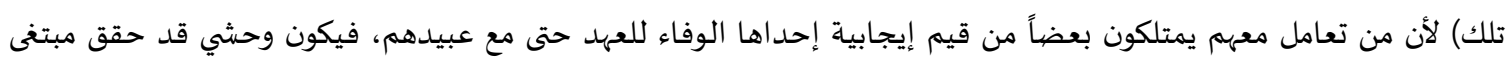

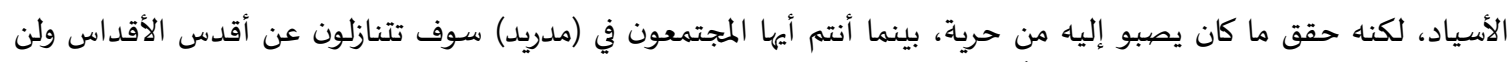

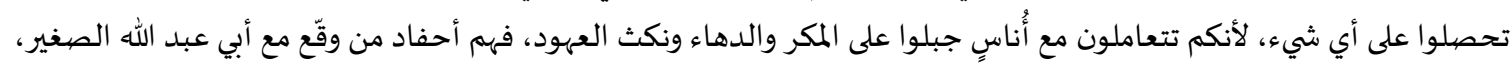

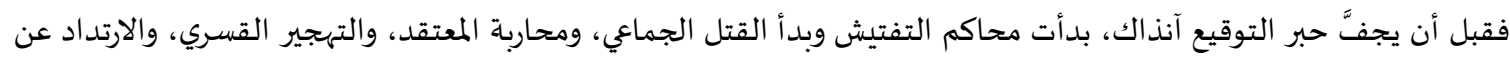

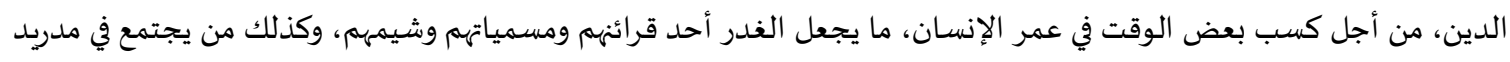

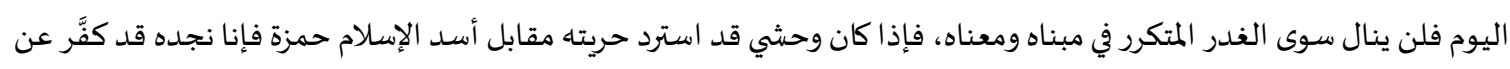

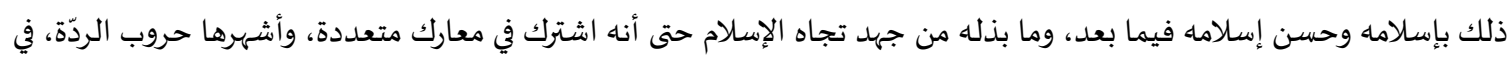

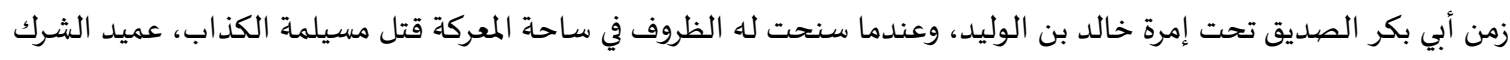

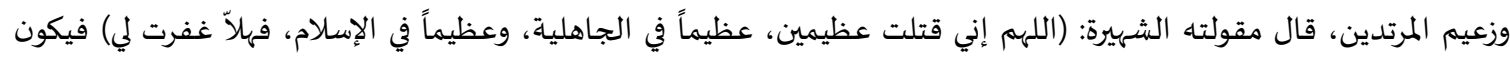

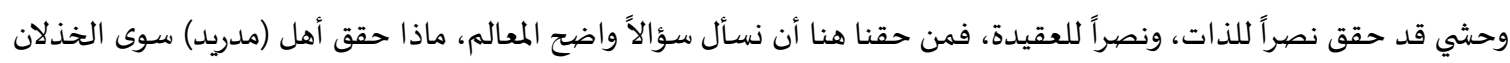

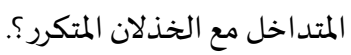

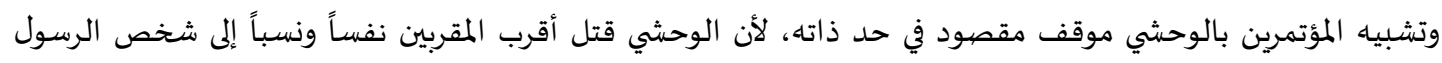

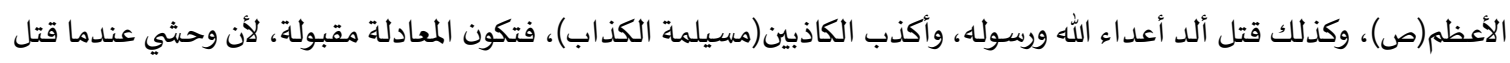

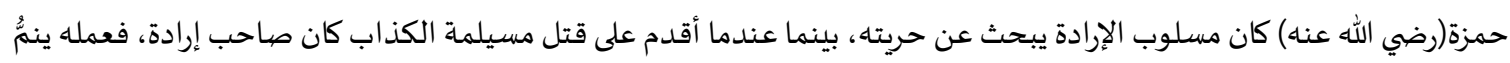

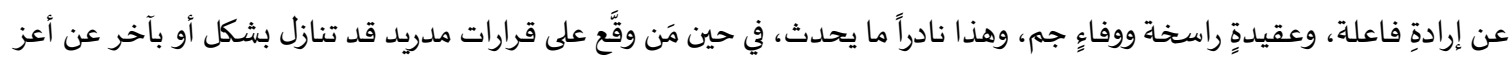

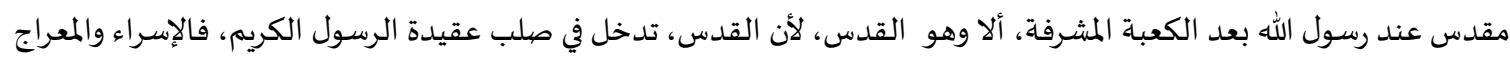

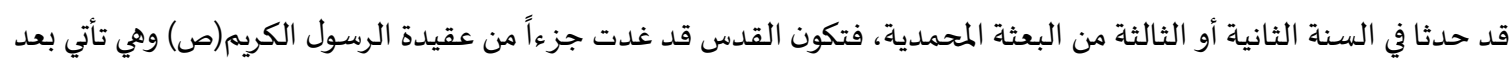

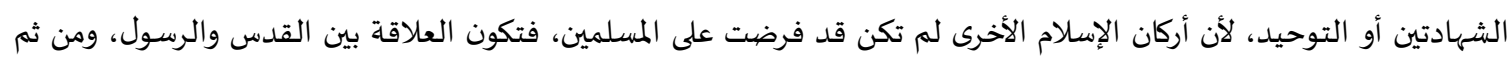

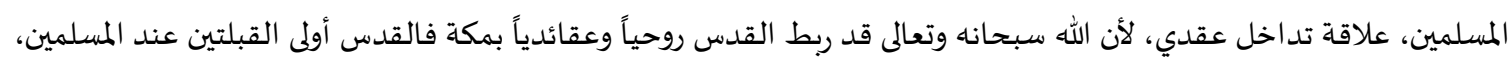

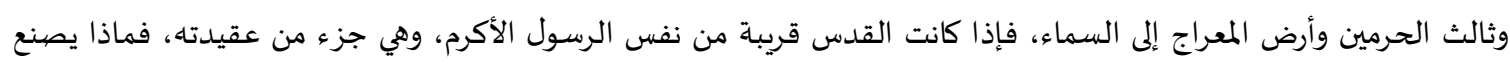

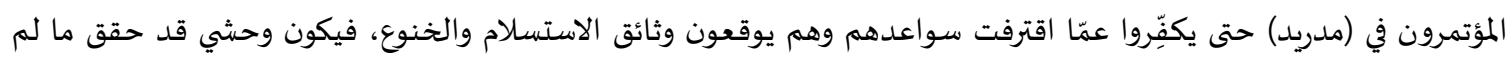

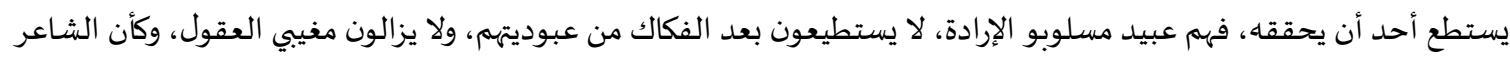

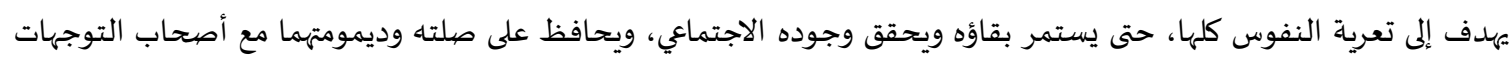

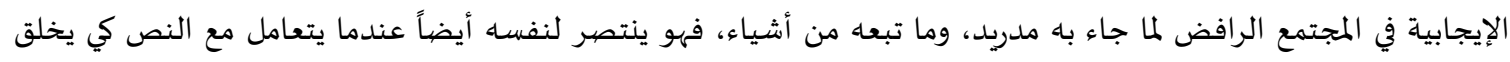


((علاقة تماس وتشابه في الآن ذاته)) .(فضل صلاح، 1992،ص 238).

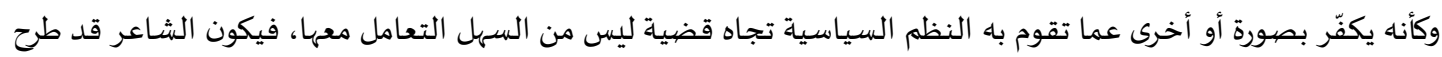

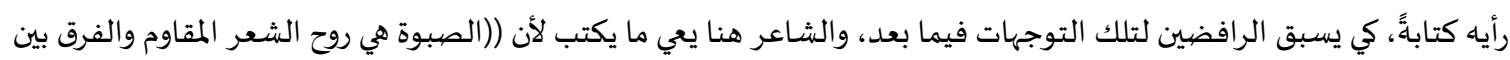

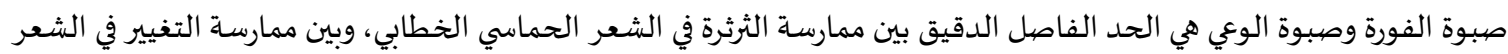

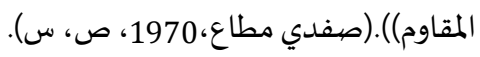

فما يكتبه الشاعر هنا هو شعر مقاومة يستند إلى رؤية وثقافة فاعلتين، على الرغم من عودة الشاعر إلى الوطن نتيجة لإفرازات

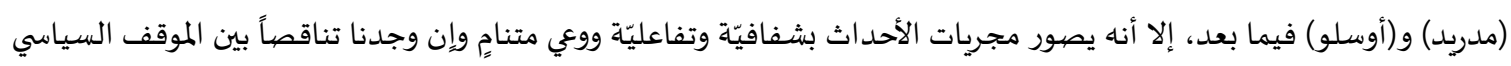
والقول الشعري.

إن موقف الشاعر من القدس جعله يتفاعل تفاعلاً معمقاً مع الحدث، ويجعل من رمزية "وحشي متنفساً "،وحالة بنائية للرؤى فئ

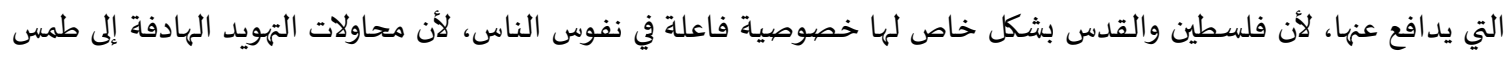
معالمها العربية والإسلامياة، تهش من جنبات الواقع المقدسي، وتجعل القدس مدينة مغرّبة أي تسودها الحضيارة الغربية (القشرية)

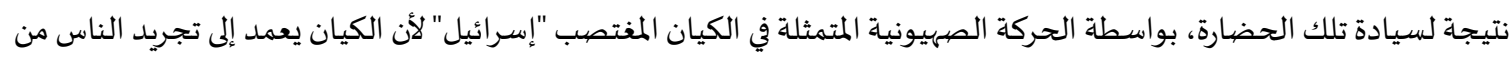

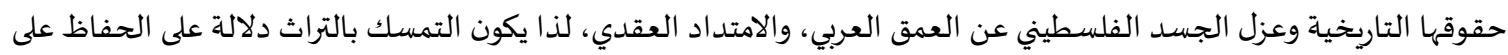

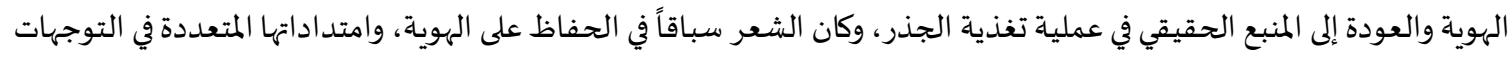

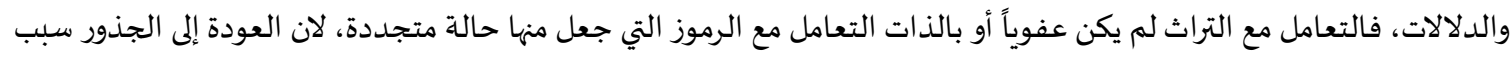

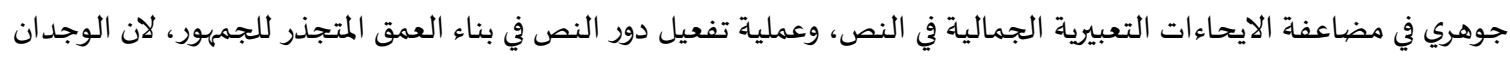

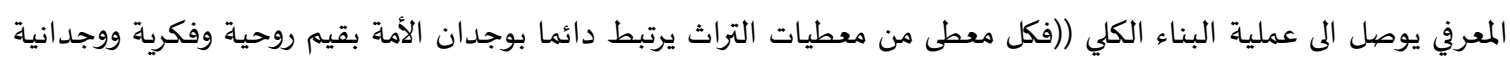

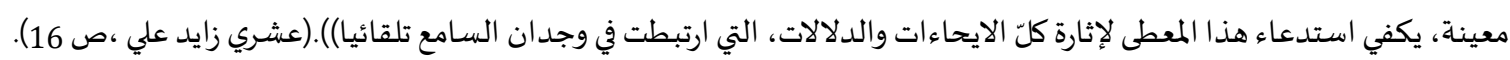

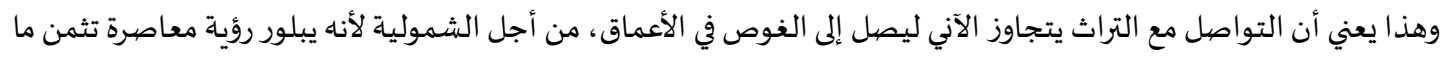

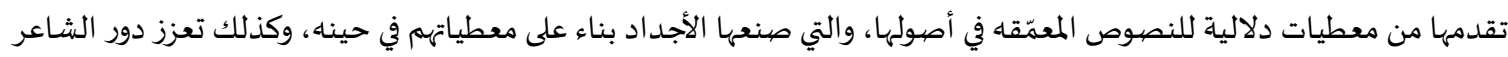

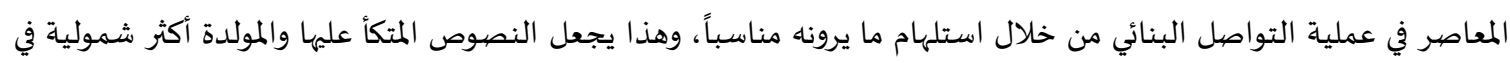

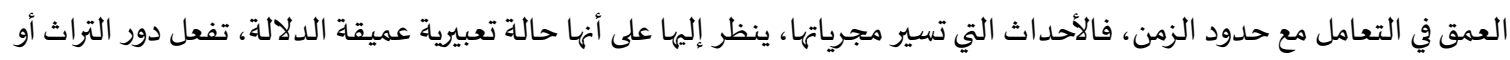
ما استمد من الماضي على وفق الادراك الشامل للهدف المراد تحقيقه ويتمثل ذلك في مفهوم عبد الوهاب البياتي في اتكائه على التراث

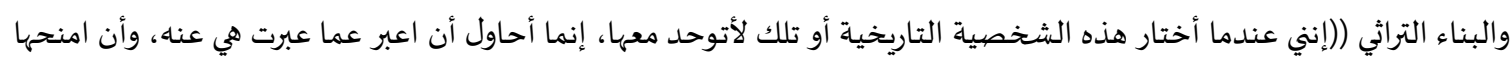

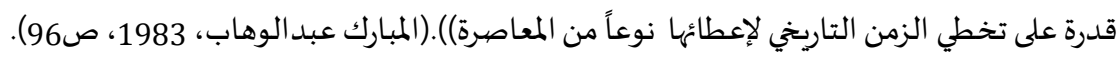

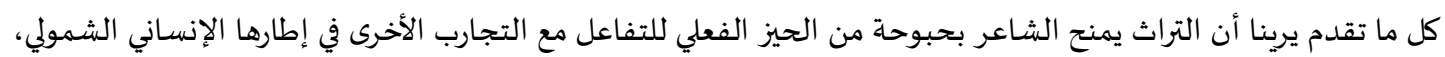

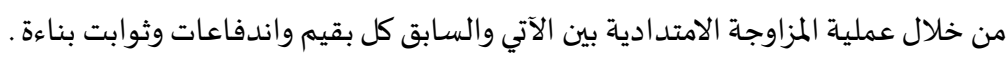

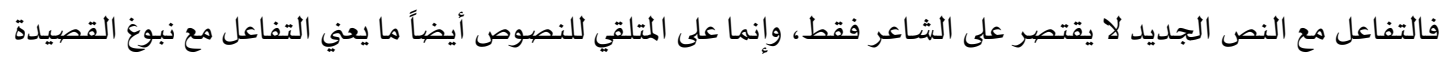

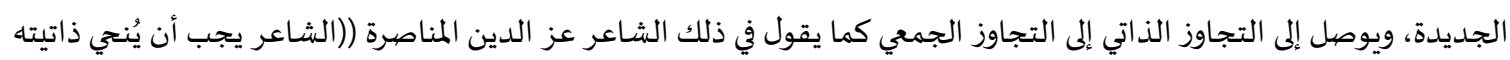

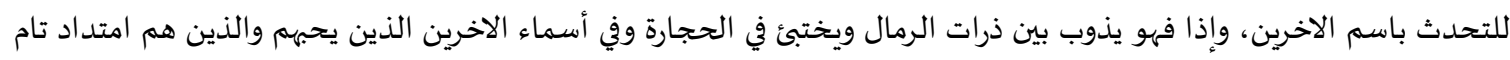

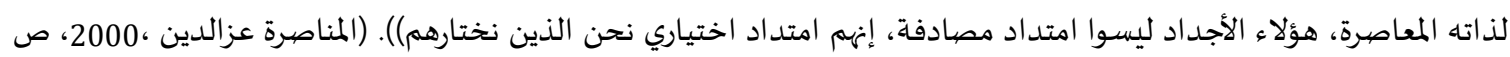

ونجد صخر حبش من الذين يعيدون الحياة الى الأساطير، أو نظم أساطير معينة في حالات نراه يصنع أساطيره التي تجسد

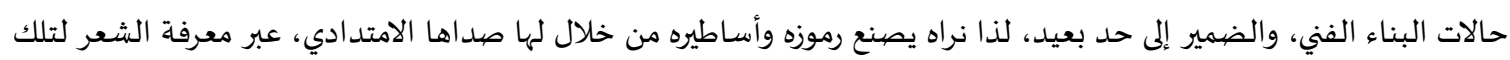
المفردات

$$
\begin{aligned}
& \text { لنا البحر .. بو ابة من خليج المنافي الى وطن الأقحوان ... } \\
& \text { وفي الزمن تركب الريح وفيه المزامير منقوشة في الهواء }
\end{aligned}
$$

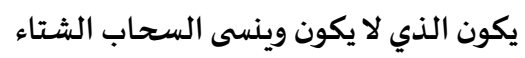

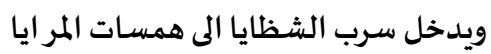

$$
\begin{aligned}
& \text { وينتج صدر الحكايا رنين الدخان }
\end{aligned}
$$

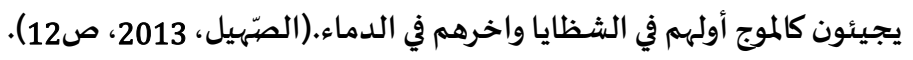


فالبحر عند صخر نراه حالة رمزية خاصة، ونراه ميّالاً إلى أسطرته، لما حمله من دلالات عميقة وفاعلة حيث ترك انعكاساً في

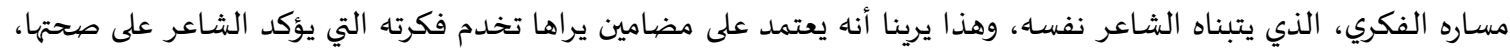

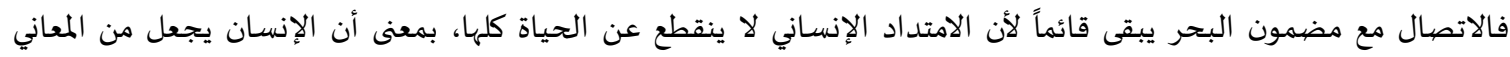

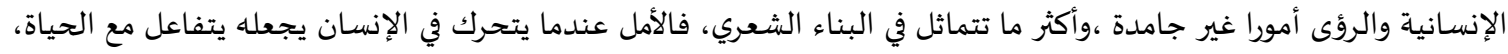

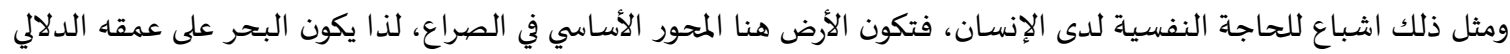

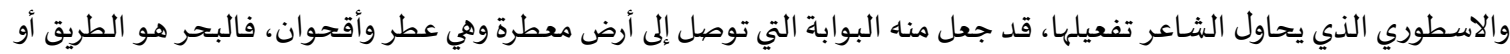

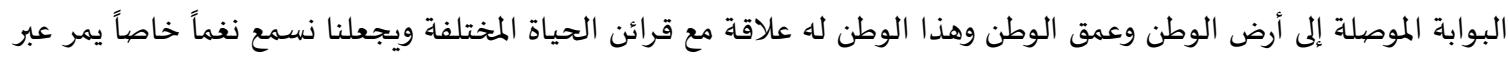

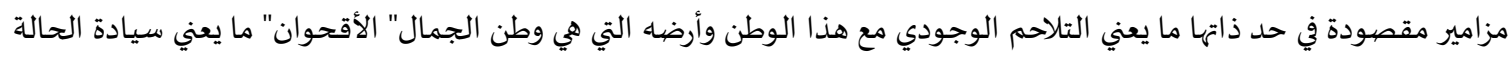

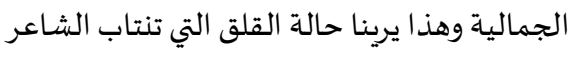

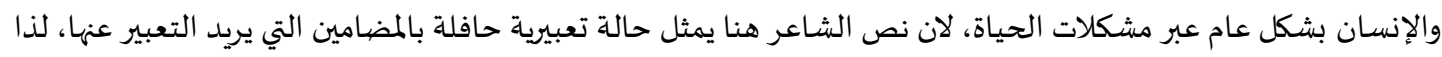

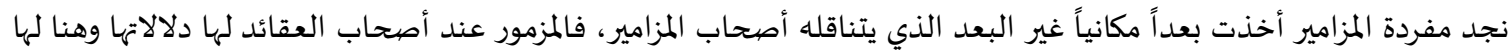

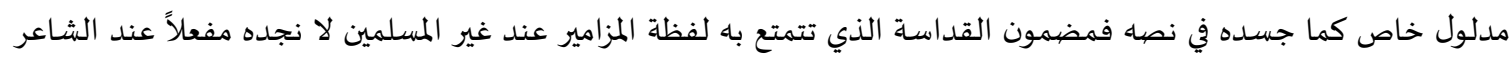

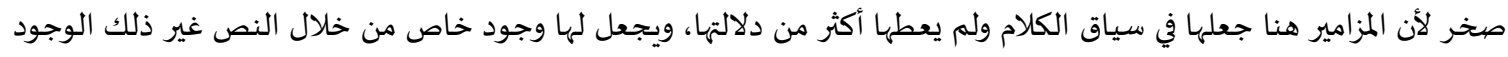

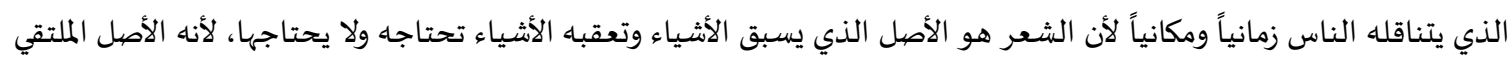

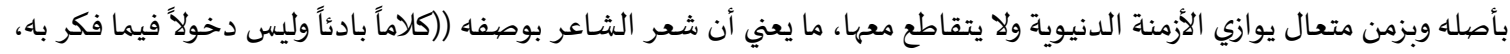

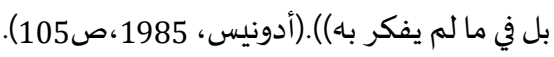

\section{يقول المغني الذي عزف الشعران فلسطين أرض القداسة}

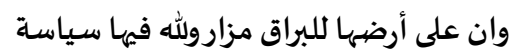

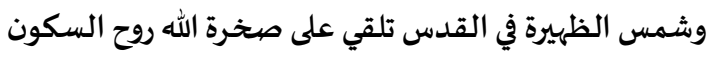

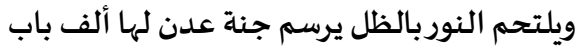

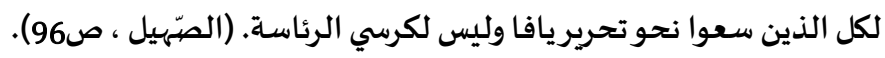

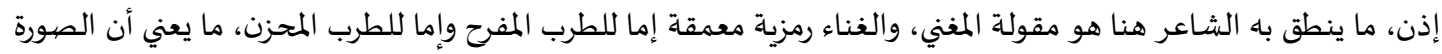

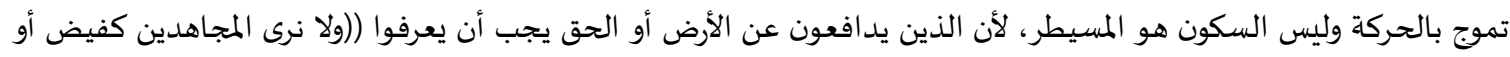

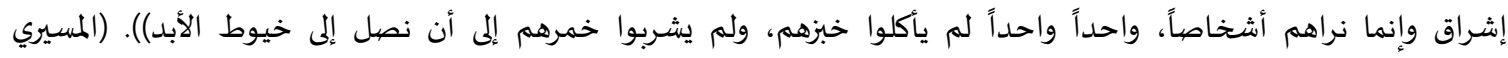

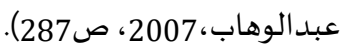

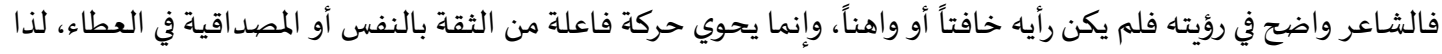

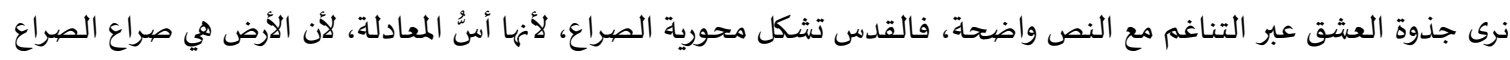

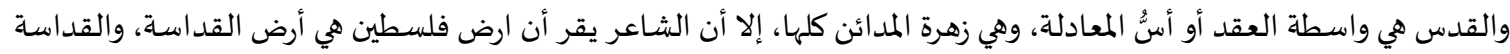

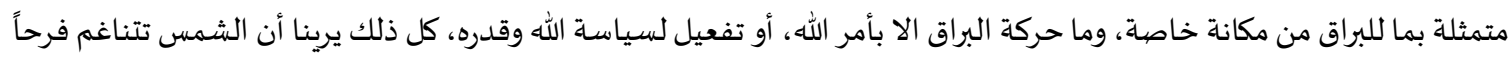

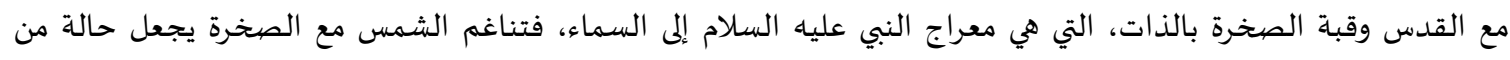

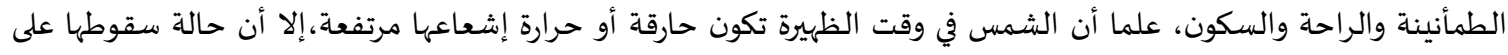

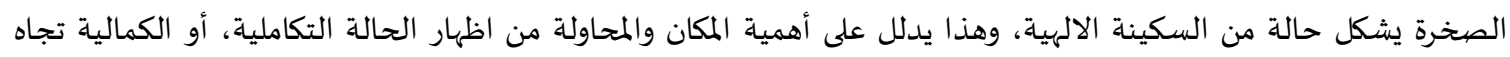

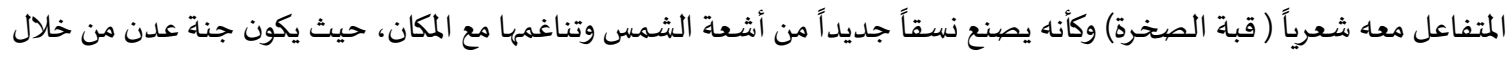

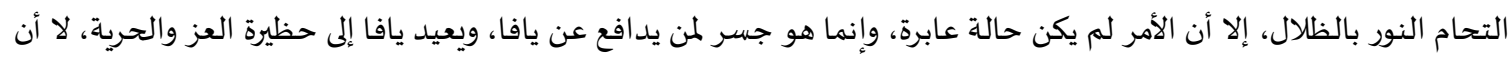

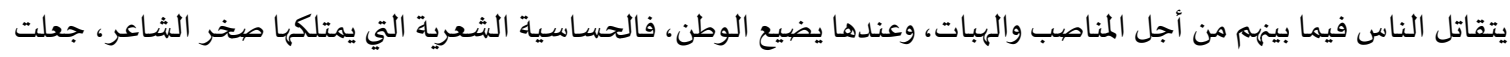

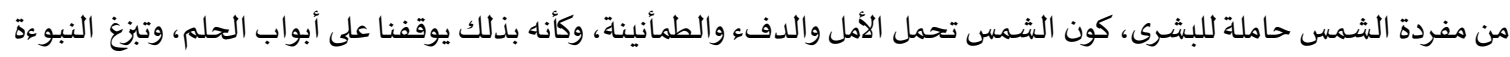

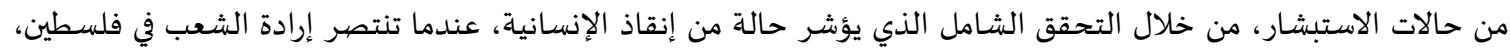

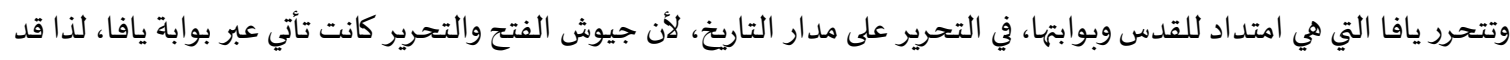

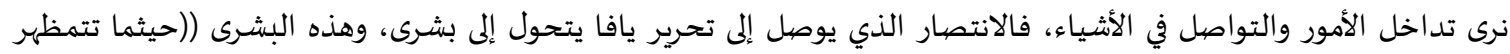

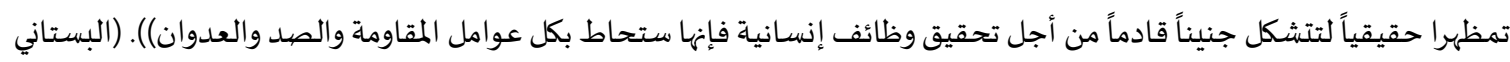




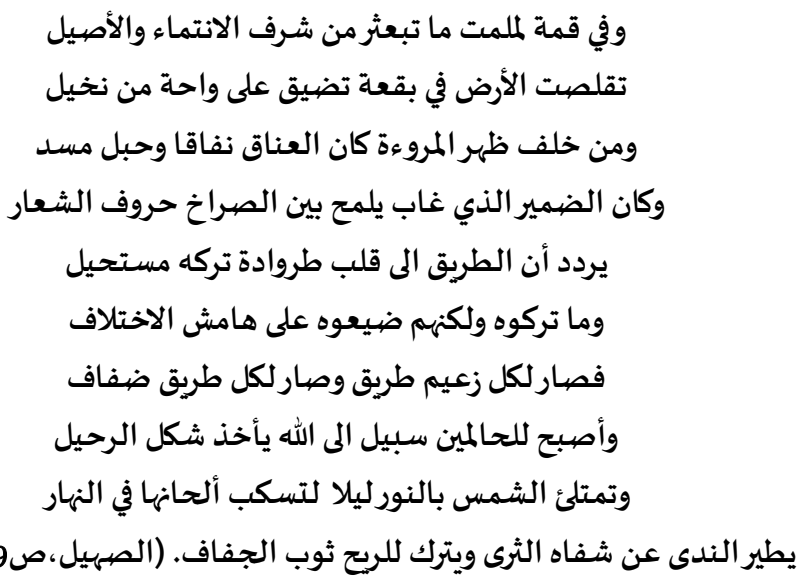

وكأننا نرى أن الشعر هنا خالد لذاته، أي أن المعادلة التي يتبعها تظهر حالة من التناغم مع المحيط واسرار الكون، وكأن المطلق

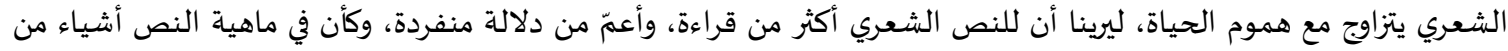

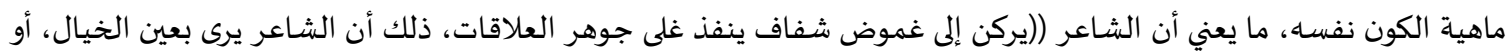

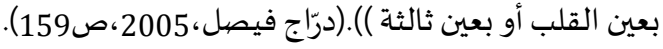

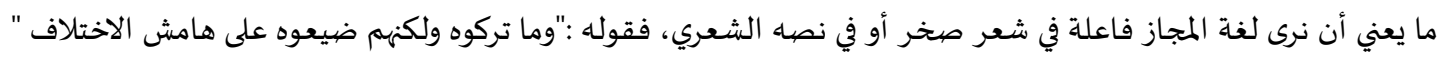

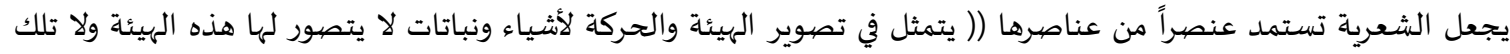

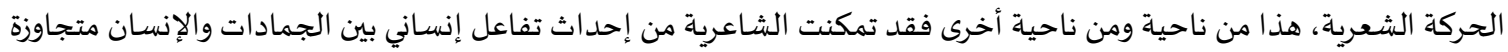

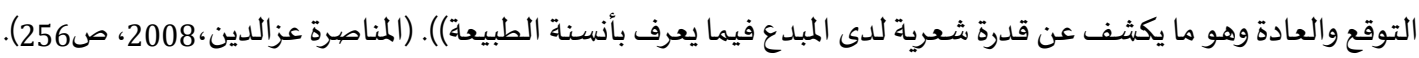

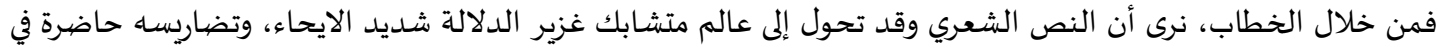

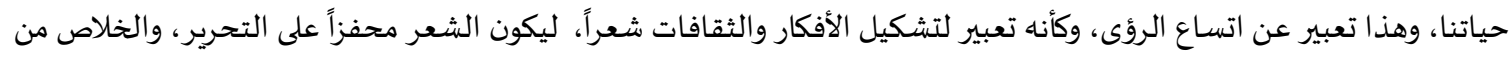

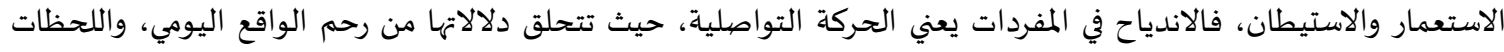

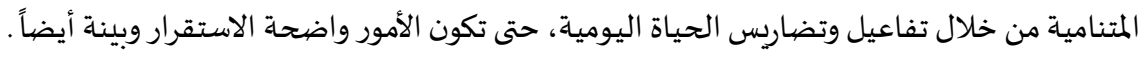

$$
\begin{aligned}
& \text { تجمعت الأرض في قبضة يطوف عليها حصيان السماء } \\
& \text { ويرسم خارطة من شواظ تفجر في الأرض سر الضياء } \\
& \text { وفوق حدود الكسوف ضفائر للشمس يصعب احر اقها } \\
& \text { تصب الشظايا على الذكريات وتسكن في بؤرة الانفجار } \\
& \text { تغطي دروب الشموع الجراح وتسكب في الروح سحر الاباء }
\end{aligned}
$$

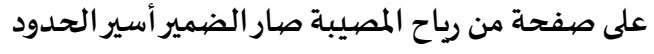

$$
\begin{aligned}
& \text { ملونة باغتصهاب الهواء مكبلة بالغبار الحقود } \\
& \text { يطوق فجر السحاب المعاني ويصببغها بهدير الدماء }
\end{aligned}
$$

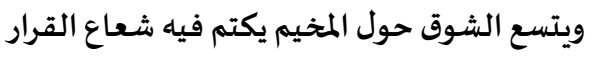

ومن مطرتتشظّى الدماء وتعصف بالشوق شمس الورود. (الَّهّهيل، ص 158).

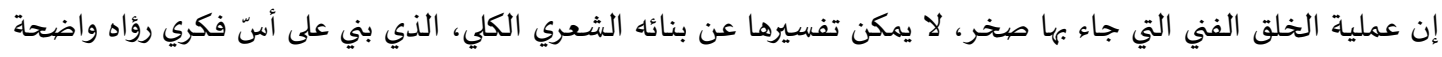

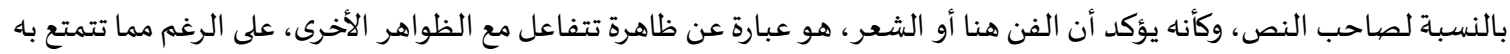

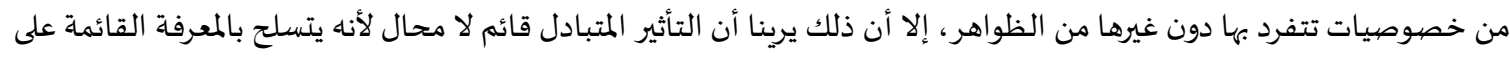

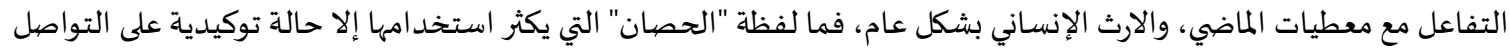

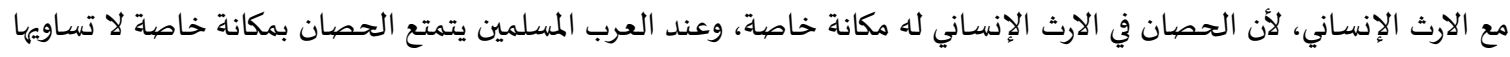

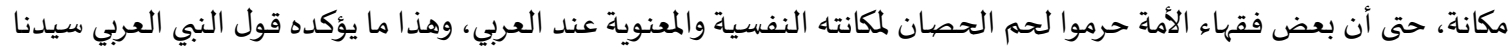

محمد صلى الله عليه وسلم، (الخيل معقود في نواصيها الخير إلى يوم القيامة). 
فحصان طروادة له المكانة الخاصة لدى الأسطورة، وأصحاب الأساطير الذين يتناقلونها عبر ثقافاتهم المتعددة، ونتاجاتهم الابداعية والفنية، لأن امتدادات الفهه للأسطورة تعني أهمية وجودها في الفن، وتعني تعزيزها في النظر إلى ذهنية محضية متطورة

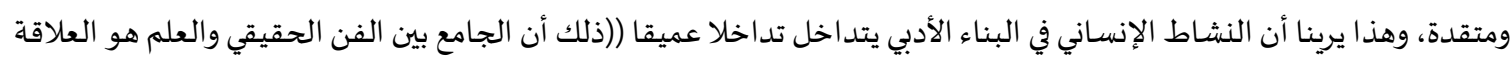
المعرفية، أي قدرة كل منهما على كشف حقائق الواقع الموضوعي (الطبيعة- المجتمع) وفهم قوانين حركته وصيرورته)) .(مروّة حسين، د. د. ت، ص61) وكأن الأرض هنا غدت وحدة واحدة تراها مجتمعة في قبضة، تجعل من ذاتها مهادا ل "حصان السماء"، وحصان السماء هنا له دلالة خاصة باء، بمعنى نجد الشاعر وقد استند إلى القران الكريم في نسج الصورة الشعرية الأولى (تجمعت الأرض في قبضية) إلى قوله

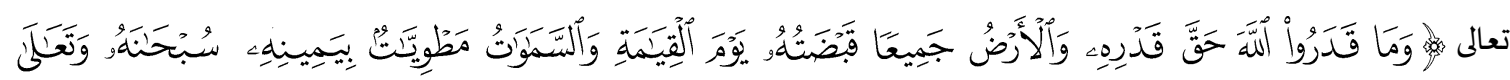

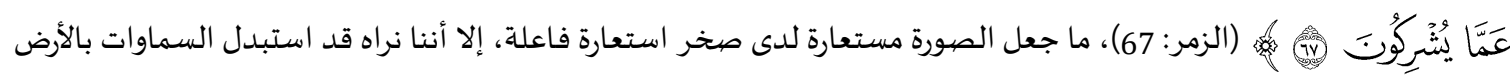

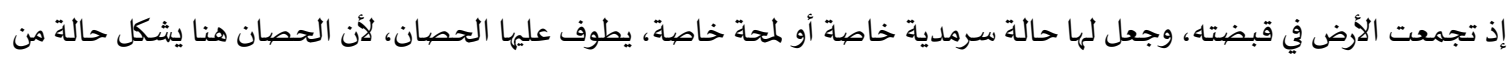

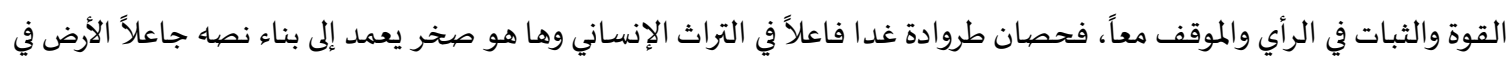

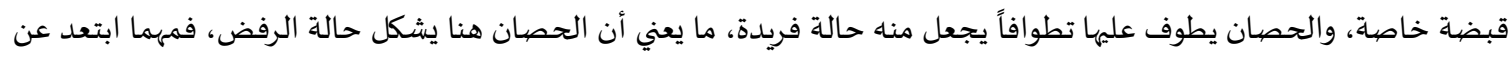
أس الأسطورة أو اقترب منها نراه يقترب من النواة التي بنيت على أساسها مركزية الأسطورة، وهي جعل جسد حصان فيان طروادة معباً

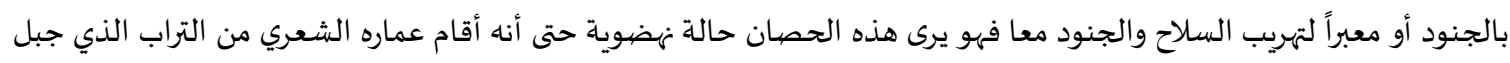

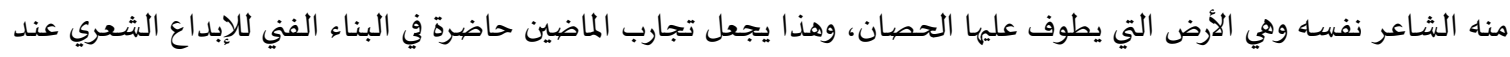

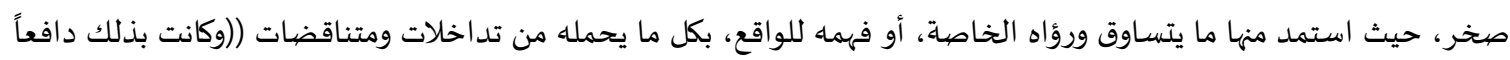

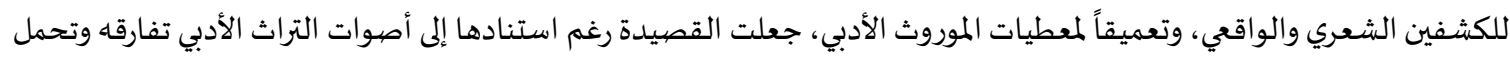

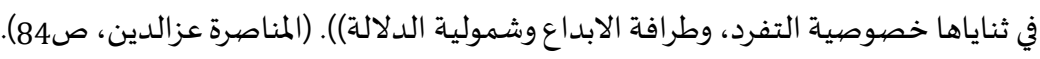

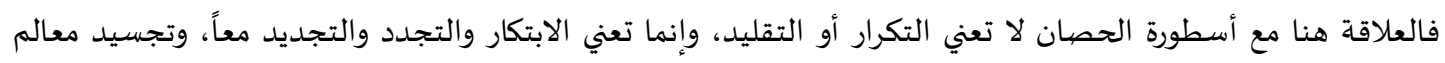

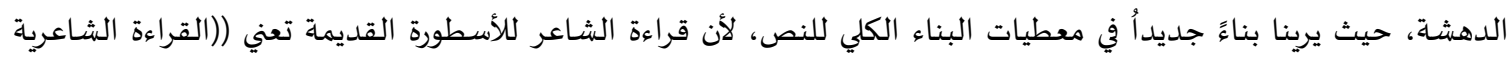

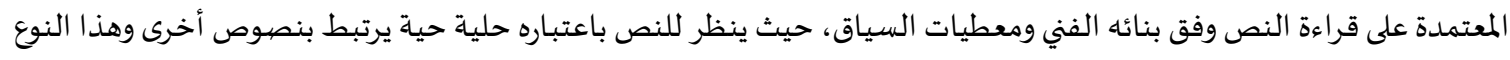

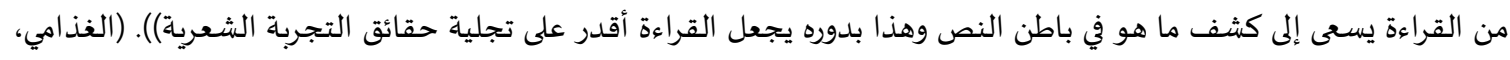

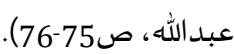

لذا نرى الأسطورة تشكل منبعاً من منابع الإلهام الشعري، الذي يسعى لارتداد إلى روحية العصر الفاعلة، حتى يجسده تجسيداً

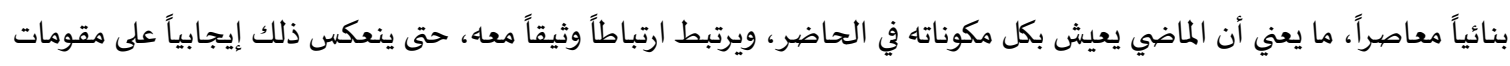
الحاضر وتفاعيل الخيال في صيدى التفاعل الايحائي مع الحياة.

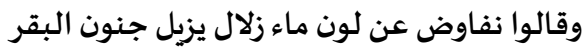

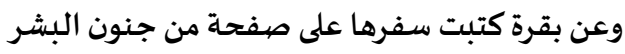 \\ وعن سدرة في الخليل تسد الطريق على شهوة الاغتصياب

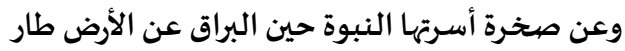 \\ وقالوا نفاوض أنتم بلا... ونحن القضياء ونحن القدر. (الصيّهيل، ص202).
}

إن استناد الشاعر على النص الديني، يعني أهمية ذلك النص وتفاعله في الحياة بشكل عام وفي نفسية الشاعر وأدائه الفني

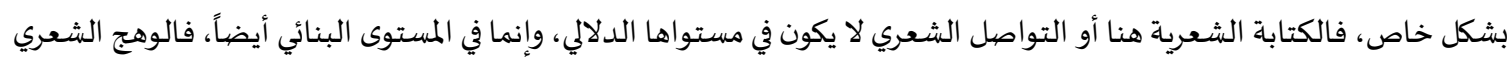

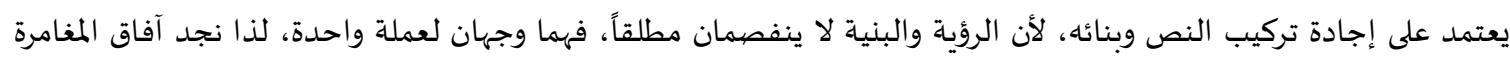

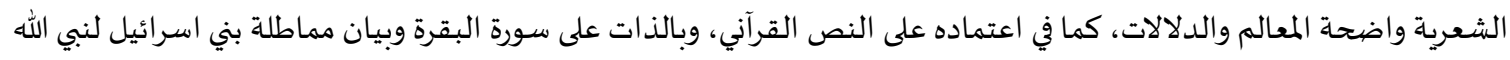
موسى عليه السلام، عندما أمرهم الله بذبح البقرة المعنية.

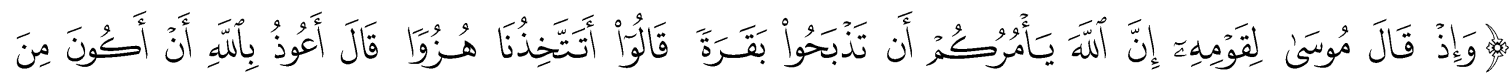

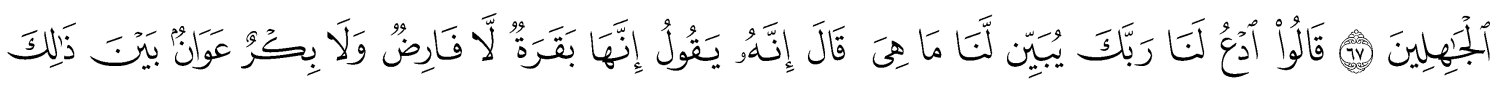




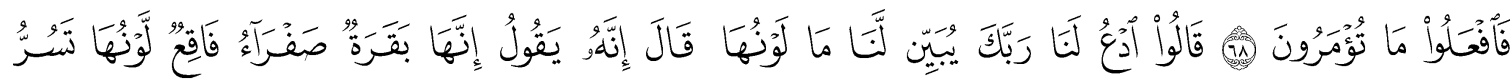

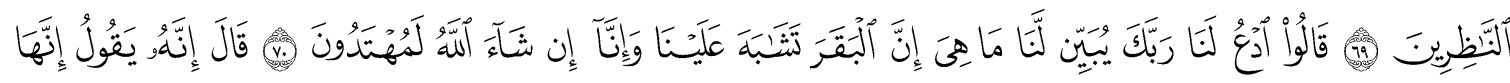

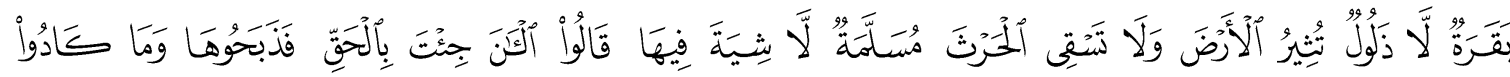

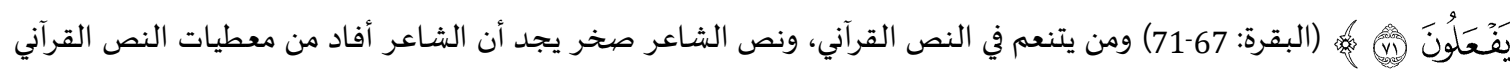

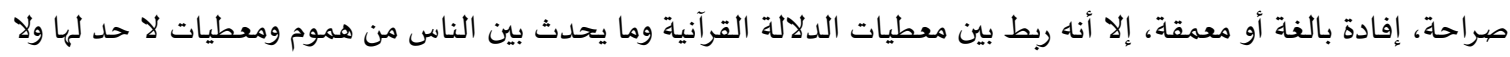

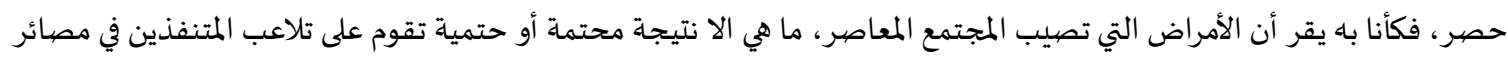

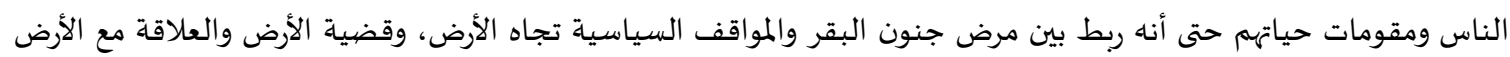

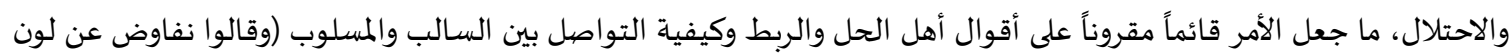

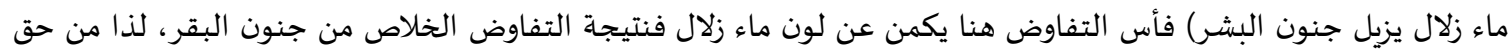

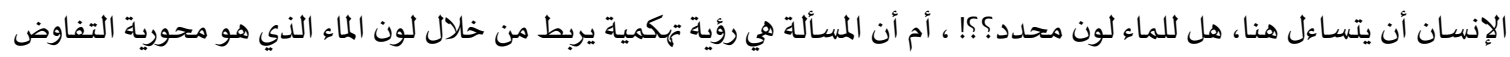

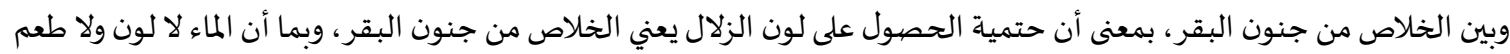

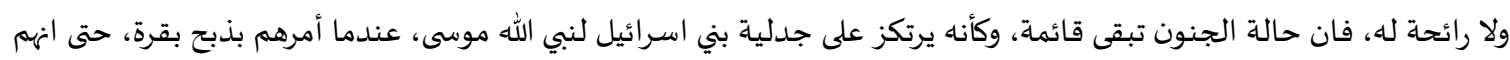

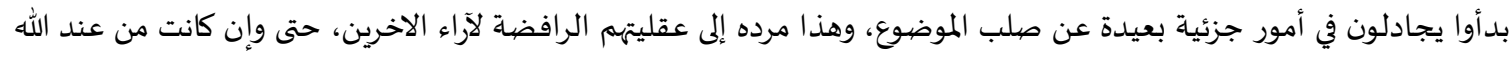

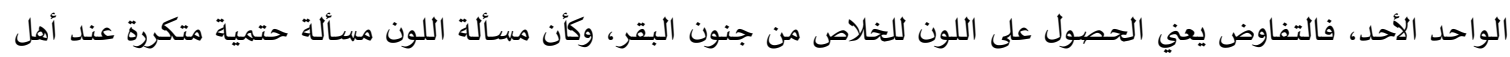

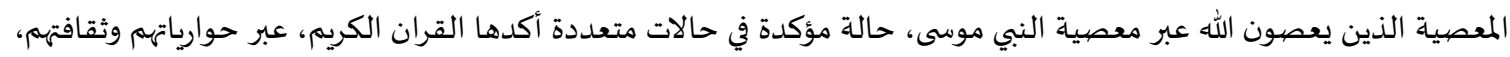

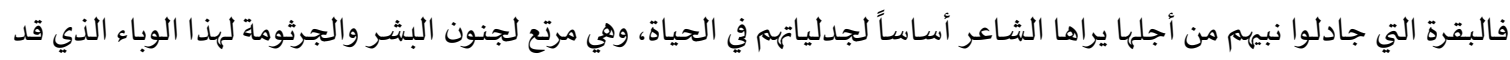

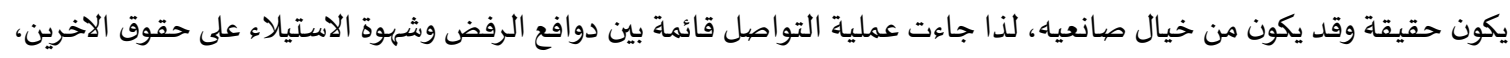

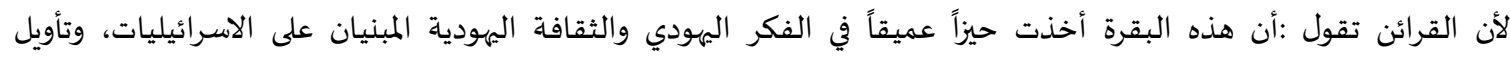
الاسرائيليات للنصوص التلمودية.

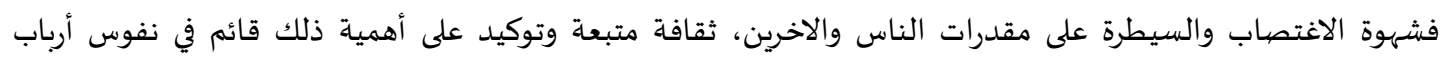

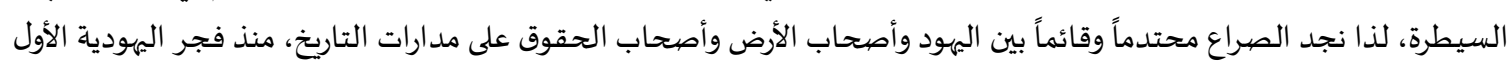

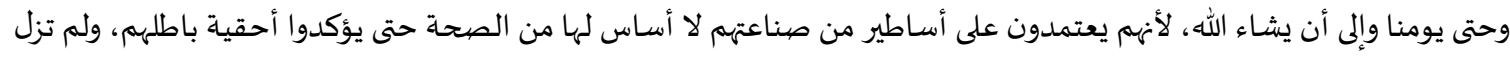

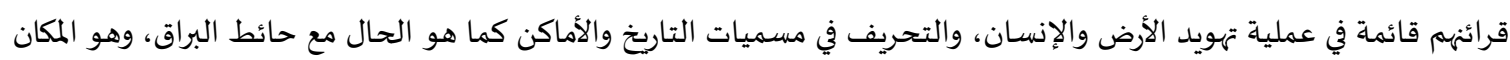

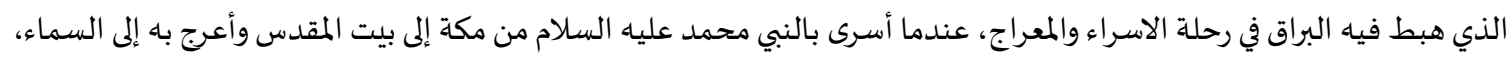

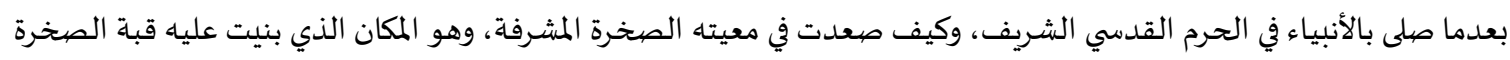

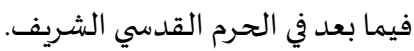

\section{وفوق الحصهار حصار القلاع وتحت الحصهارحصار الخر افة}

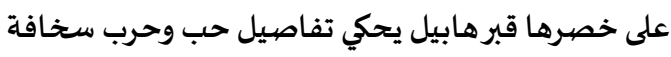

وعن طوق شمس تلملم عظم النجوم لتبعث أقمارها

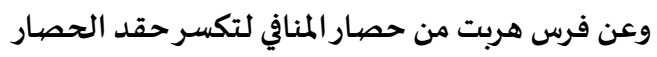

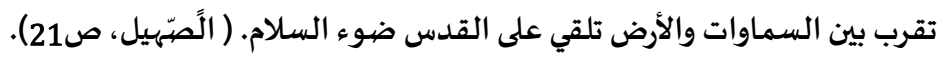

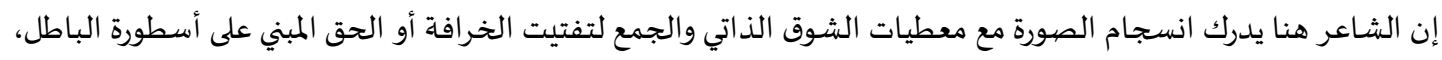

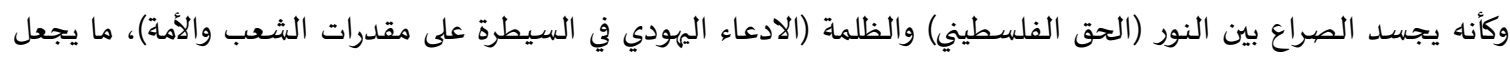

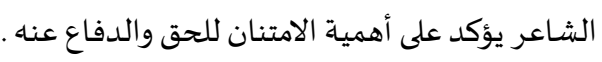

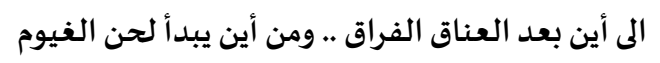

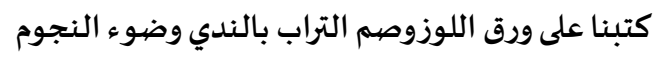

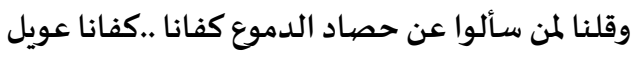

ففي نسخ أحلامنا وردة تفوح مواسمها في الجليل 


\section{وتنشرعطر الليالي نبيذا وتفضح عشق الندى للكروم. (الصّهيل، ص190).}

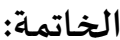

وبعد أن شخصت الدراسة في النور، وغدت مستوية على عودها، ارتائنا تدوين خلاصة فكرتنا، آلتي ضمّنتها أسطر البحث، وثنايا

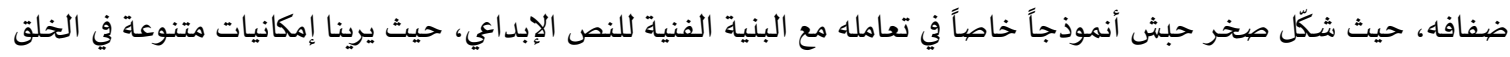

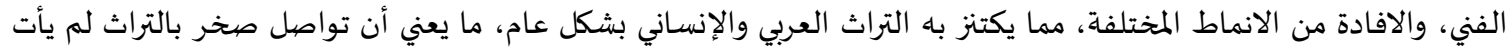

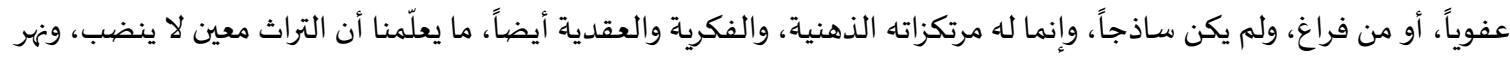

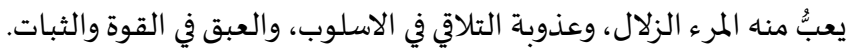

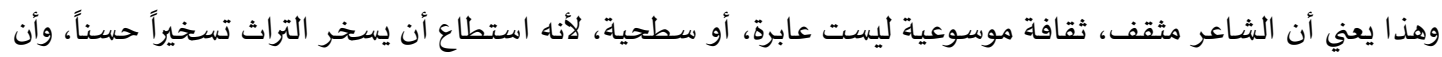

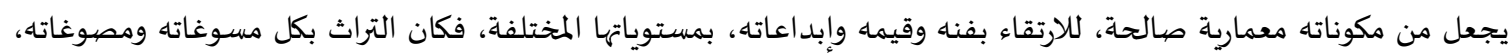

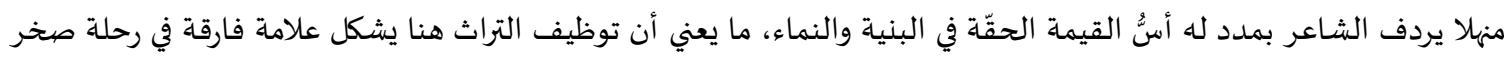

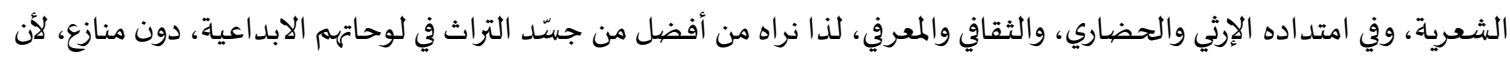

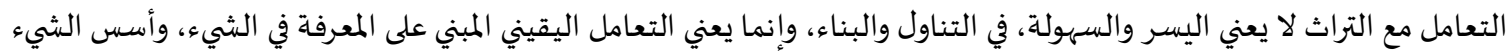

المتعددة.

من خلال النص الشعري، يتبين لنا أن تفعيل التراث عند صخر لم يكن حكراً على الشكل دون المضامين مثلاً، في معمارية نصيّه

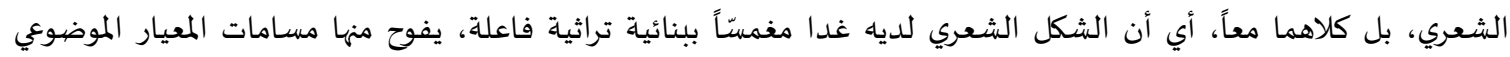

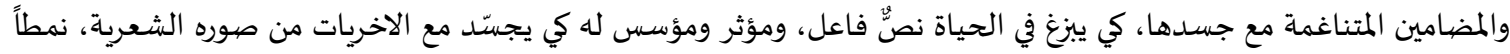

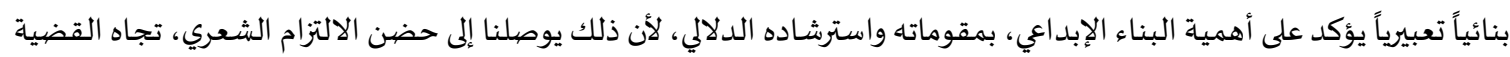

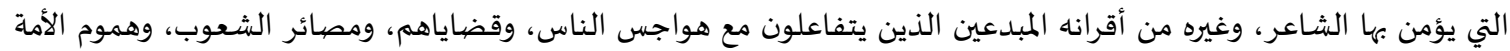
والوطن والمواطن.

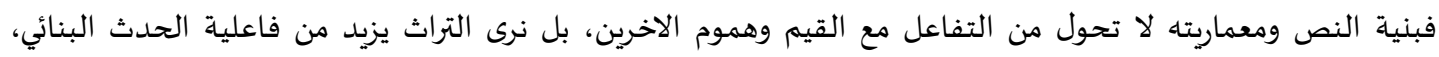

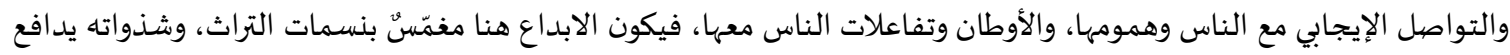

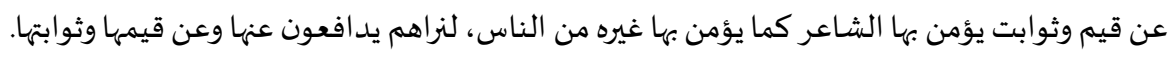

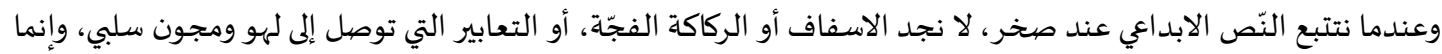

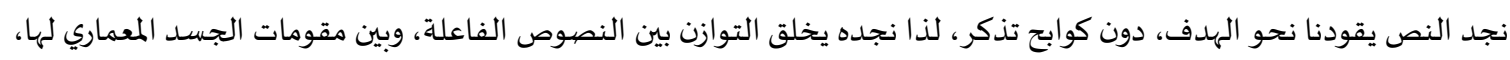

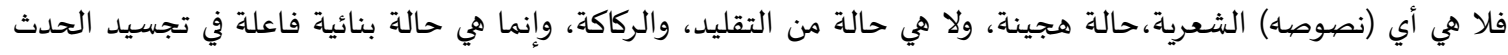

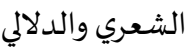

كل ذلك يرينا أنّ صخراً من الشعراء الذين حافظوا على التراث ،وفعَّلوه، تفعيلاً إيجابياً، من خلال نصيّه الذي جعل التراث التراث قيمة

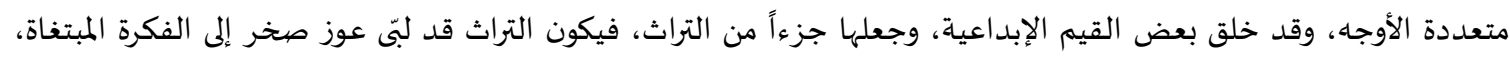

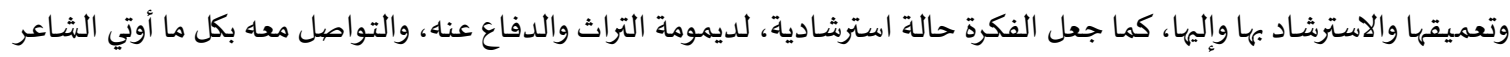

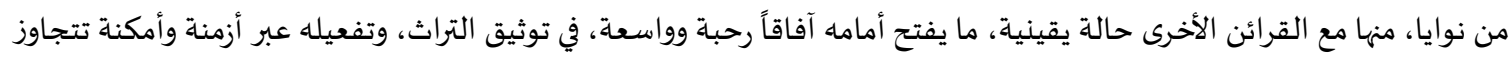

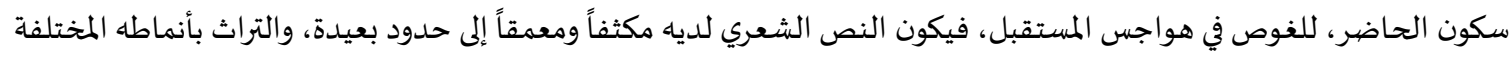

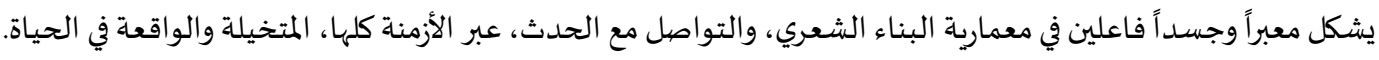

\section{المراجع:

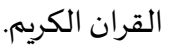

1. إسماعيل، ع.(1972). الشعر المعاصروقضياياه وظواهره الفنية والمعنوية. ط2. دار العودة ودار الثقافة. بيروت، ص 202-203. 2.

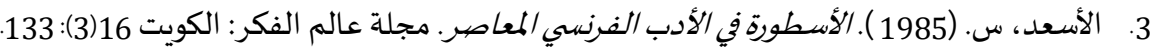

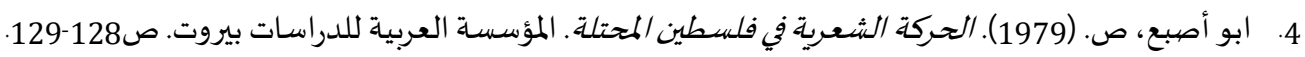

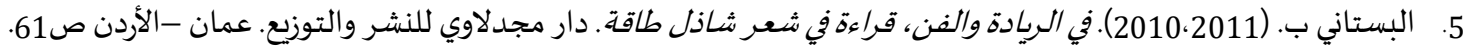

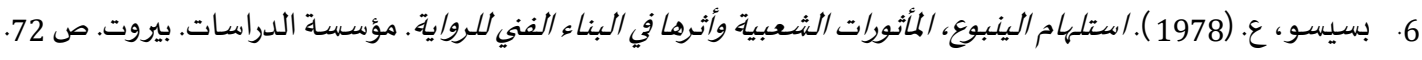


7. بلاطة، ع. (1971). بلدرشاكر السياب. حياته وشعره. دار النهار. بيروت. ص190.

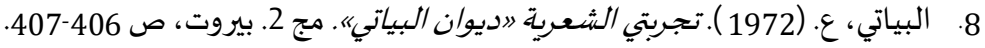

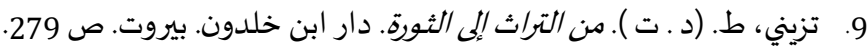

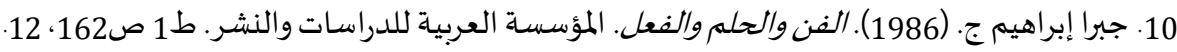

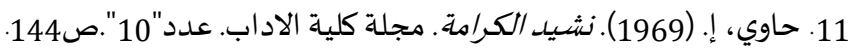
12. حبش، ص. (2013 ). الصهيل. طبعة 1. مركز صخر حبش للدراسات والتوثيق. رام الله - فلسطين. ص 12-12-96-149-150-202-

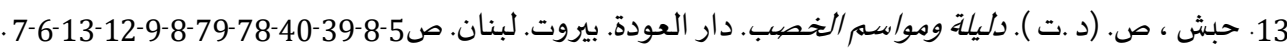

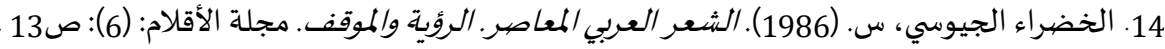

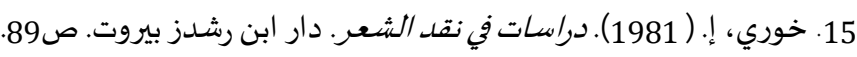

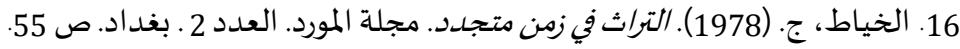

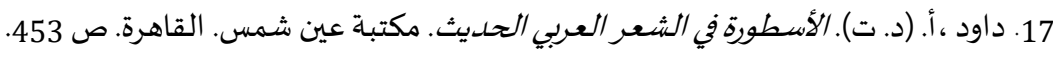
18. دراج، ف. (2005). الحداثة المتقهقر، طه حسين وأدونيس، مواطن. المؤسسة الفلسطينية لدراسـة الديموقراطية. رام اللهـ فلسطين. ص 159.

19. درويش، م. ( 1986). خمسون عاما بلا لوركا. مجلة اليوم السابع: باريس. حزيران. ص 1596-78-78.

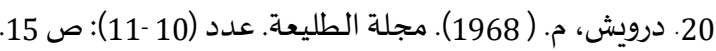
21. الديك، ن. (1988). الهجرة والانبعاث في شعر صخر حبش أبي ننار،دراسة في ملكوت الشعر والشاعر، مؤسسة العنقاء للتجديد والابداع. ط1. ص ص 229

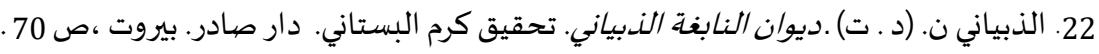
23. زايد عشري، ع. ( 1978). استـدعاء الشخصيات التراثية. الشركة العامة للنشر والتوزيع. طرابلس. ليبيا. ص 52-41-27.

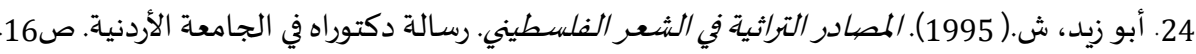

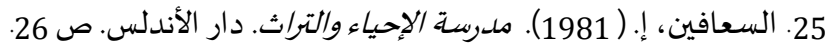

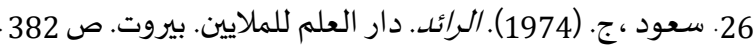

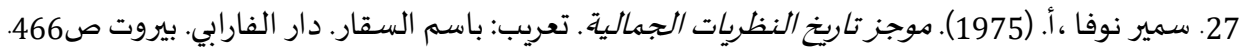

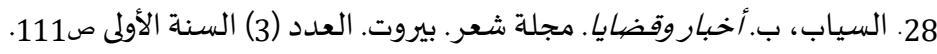
29. الصايغ، ي. ( 1978). الشعبر الحرفي العراق حتى عام 1958 بغداد. د. مطبعة رمزي. ص 162.

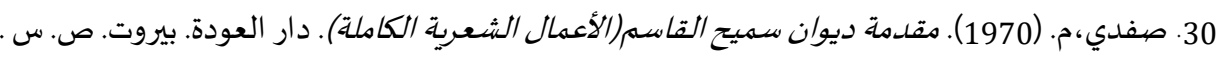

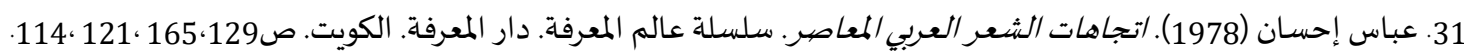
32. العبطة، م. (1957). بلد شاكر السياب والحركة الشعرية الجديدة في العراق - مجلة الفنون: (22): ص 86-87.

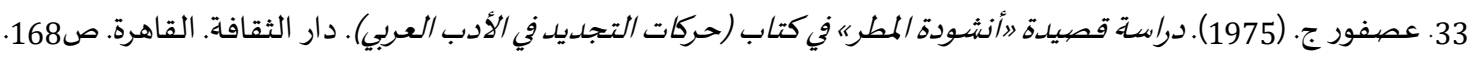
34. غالي ،ش. (1973). التراث والثورة. ط2. دار الطليعة. بيروت. ص 245.

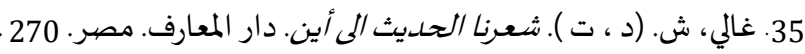

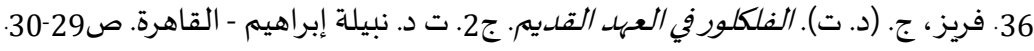

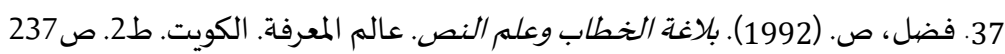

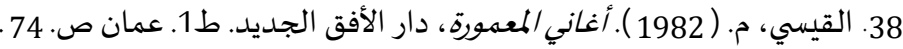

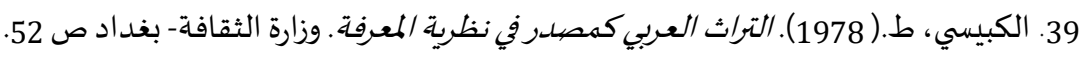

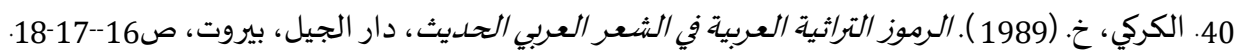

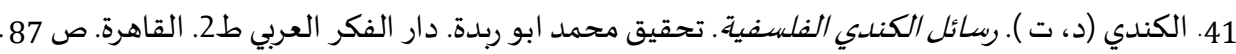

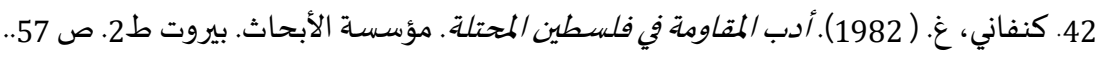

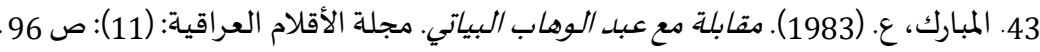

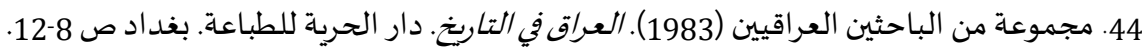


45. مجموعة من النقاد.( 1973). الأسطورة والرمز. ترجمة جبرا إبراهيم جبرا. وزارة الاعلام بغداد. ص 233.

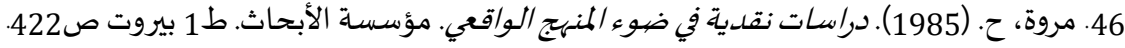

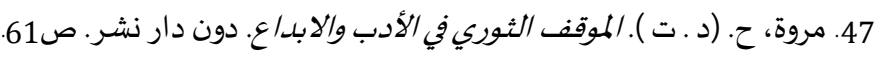

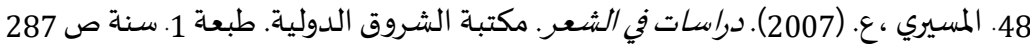

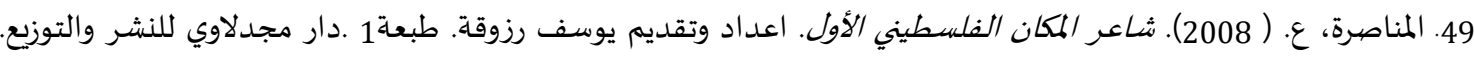
عمان-الأردن ص 256. 50. مناصرة، ع. (2000). شاعرية التاريخ والأمكنة. (حوارات صحافية مع الشاعر المناصرة) المؤسسة العربية للدراسات والنشر. طبعة 1 عمان. ص 118.

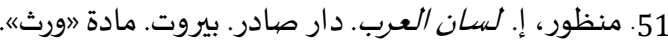

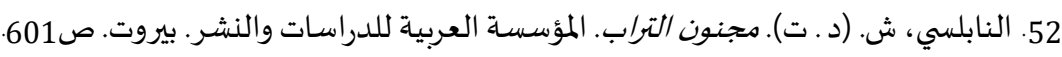

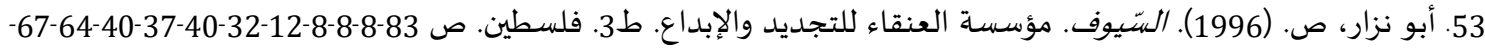
80-75

54. أبو نزار، ص. (1997 ). الصهيل. مؤسسة العنقاء للتجديد والابداع. ط1 ص32.

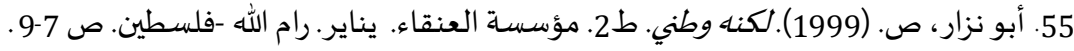

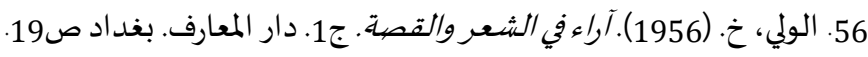

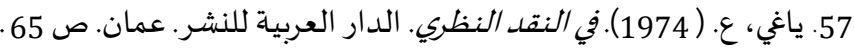
58. يقطين، س. (1992). الرواية والتراث السردي من أجل وعي جديد بالتراث. المركز الثقافي بيروت. ص126. 
المجلة الدولية للدراسات اللغوية والأدبية العربية

International Journal for Arabic Linguistics and Literature Studies (JALLS)

www.refaad.com

Journal Homepage: https://www.refaad.com/views/JALS/home.aspx ISSN: 2663-5860(Online) 2663-5852(Print)

\title{
Heritage in the poetry of sakhr Habash Abi Nizar (Part Two)
}

\author{
Nadi Sari Al-Deek \\ Professor at Al-Quds Open University, Palestine \\ nadishameem@yahoo.com
}

Received : 2/3/2021 Revised : 20/3/2021 Accepted : 8/4/2021 DOI : https://doi.org/10.31559/JALLS2021.3.2.1

\begin{abstract}
Heritage is a word that has its own significant meaning in the minds of literature creators and recipients alike, making contemporary poets interact with it through their creative texts, Sakhr Habash is one of those poets who have made heritage as an effective one with all its components, and its strength in their poetic texts, He started to create a completed poetry status full of heritage images and achievements, humanitarian heritage was present, spiritual Arab and Islamic heritage was very clear and sequential in his poetic texts, which makes his poem teeming with viable heritage and its components, whether through traditional characters or titles or creative different original texts, religious or literature, were he used to depend on for his poetry, and this does not mean that he made a heavy load on the spiritual heritage text, but we find him building his texts decorated with heritage that enriches the text and make it close to the minds of those who receive it, and those who interact with it, because heritage became an active factor in Sakhr Habash poetic poem.
\end{abstract}

\section{Keywords: Poetic texts; heritage; literature.}

\section{References:}

- Alqran Alkrym.

1. 'bas Ehsan (1978). Atjahat Alsh'r Al'rby Alm'asr. Slslt 'alm Alm'rfh. Dar Alm'rfh. Alkwyt. S165,129, 121, 114.

2. Al'bth, M. (1957). Bdr Shakr Alsyab Walhrkh Alsh'ryh Aljdydh Fy Al'raq - Mjlt Alfnwn: (22): S 86-87.

3. 'sfwr J. (1975). Drash Qsydh «Anshwdh Almtr» Fy Ktab (Hrkat Altjdyd Fy Aladb Al'rby). Dar Althqafh. Alqahrh. S168.

4. Alas'd, S. (1985). Alastwrh Fy Aladb Alfrnsy Alm'asr. Mjlt 'alm Alfkr: Alkwyt 16(3): 133.

5. Abw Asb', S. (1979). Alhrkh Alsh'ryh Fy Flstyn Almhtlh. Alm'ssh Al'rbyh Lldrasat Byrwt. S128-129.

6. Blath, '. (1971). Bdr Shakr Alsyab. Hyath Wsh'rh. Dar Alnhar. Byrwt. S190.

7. Albstany B. (2010,2011). Fy Alryadh Walfn, Qra'h Fy Sh'r Shadl Taqh. Dar Mjdlawy Llnshr Waltwzy'. 'man -Alardn S61.

8. Bsysw, '. (1978). Astlham Alynbw', Almathwrat Alsh'byh Wathrha Fy Albna' Alfny Llrwayh. M'sst Aldrasat. Byrwt. $\mathrm{S} 72$.

9. Albyaty, '. (1972). Tjrbty Alsh'ryh «Dywan Albyaty». Mj 2. Byrwt, S 406-407.

10. Dawd, A. (D. T). Alastwrh Fy Alsh'r Al'rby Alhdyth. Mktbh 'yn Shms. Alqahrh. S 453.

11. Draj, F. (2005). Alhdathh Almtqhqrh, Th Hsyn Wadwnys, Mwatn. Alm'ssh Alflstynyh Ldrash Aldymwqratyh. Ram Allh-Flstyn. S 159.

12. Drwysh, M. (1968). Mjlt Altly'h. 'dd (10 -11): S 15.

13. Drwysh, M. (1986). Khmswn 'ama Bla Lwrka. Mjlt Alywm Alsab': Barys. Hzyran. S 76-78. 
14. Adwnys (1985). Syash Alsh'r. Dar Aladab. Byrwt. S 42, 105.

15. Aldyk, N. (1988). Alhjrh Walanb'ath Fy Sh'r Skhr Hbsh Aby Nzar, Drash Fy Mlkwt Alsh'r Walsha'r, M'sst Al'nqa' Lltjdyd Walabda'. T1. S 229

16. Aldbyany N. (D. T) Dywan Alnabghh Aldbyany. Thqyq Krm Albstany. Dar Sadr. Byrwt, S 70.

17. Esma'yl, '. (1972). Alsh'r Alm'asr Wqdayah Wzwahrh Alfnyh Walm'nwyh. T2. Dar Al'wdh Wdar Althqafh. Byrwt, S 202-203.

18. Fdl, S. (1992). Blaghh Alkhtab W'Im Alns. 'alm Alm'rfh. Alkwyt. T2. S237.

19. Fryz, J. (D. T). Alflklwr Fy Al'hd Alqdym. J2. T D. Nbylh Ebrahym - Alqahrh. S29-30.

20. Ghaly, Sh. (1973). Altrath Walthwrh. T2. Dar Altly'h. Byrwt. S 245.

21. Ghaly, Sh. (D, T). Sh'rna Alhdyth Ala Ayn. Dar Alm'arf. Msr. 270.

22. Hawy, E. (1969). Nshyd Alkramh. Mjlt Klyh Aladab. 'dd"10". S144.

23. Hbsh, S. (2013). Alshyl. Tb'h 1. Mrkz Skhr Hbsh Lldrasat Waltwthyq. Ram Allh - Flstyn. S 12-96-149-150202-21.

24. Hbsh, S. (D.T). Dlylh Wmwasm Alkhsb. Dar Al'wdh. Byrwt. Lbnan. S5-8-39-40-78-79-8-9-12-13-6-7.

25. Jbra Ebrahym J. (1986). Alfn Walhlm Walf'l. Alm'ssh Al'rbyh Lldrasat Walnshr. T1 S162, 12.

26. Alkbysy, T. (1978). Altrath Al'rby Kmsdr Fy Nzryt Alm'rfh. Wzarh Althqafh- Bghdad S 52.

27. Alkhdra' Aljywsy, S. (1986). Alsh'r Al'rby Alm'asr. Alr'yh Walmwqf. Mjlt Alaqlam: (6): S13.

28. Alkhyat, J. (1978). Altrath Fy Zmn Mtjdd. Mjlt Almwrd. Al'dd 2. Bghdad. S 55.

29. Alkndy (D, T). Rsa'l Alkndy Alflsfyh. Thqyq Mhmd Abw Rbdh. Dar Alfkr Al'rby T2. Alqahrh. S 87.

30. Knfany, Gh. (1982). Adb Almqawmh Fy Flstyn Almhtlh. M'sst Alabhath. Byrwt T2. S 57.

31. Alkrky, Kh. (1989). Alrmwz Altrathyh Al'rbyh Fy Alsh'r Al'rby Alhdyth, Dar Aljyl, Byrwt, S16--17-18.

32. Khwry, E. (1981). Drasat Fy Nqd Alsh'r. Dar Abn Rshdz Byrwt. S89.

33. Almbark, '. (1983). Mqablh M' 'bd Alwhab Albyaty. Mjlth Alaqlam Al'raqyh: (11): S 96.

34. Mjmw'h Mn Albahthyn Al'raqyyn (1983). Al'raq Fy Altarykh. Dar Alhryh Lltba'h. Bghdad S 8-12.

35. Mjmw'eh Mn Alnqad. (1973). Alastwrh Walrmz. Trjmt Jbra Ebrahym Jbra. Wzart Ala'lam Bghdad. S 233.

36. Almnasrh, '. (2008). Sha'r Almkan Alflstyny Alawl. A'dad Wtqdym Ywsf Rzwqh. Tb'h1. Dar Mjdlawy Llnshr Waltwzy'. 'man-Alardn S 256.

37. Mnasrh, '. (2000). Sha'ryt Altarykh Walamknh. (Hwarat Shafyh M' Alsha'r Almnasrh) Alm'ssh Al'rbyh Lldrasat Walnshr. Tb'h 1 'man. S 118.

38. Mnzwr, E. Lsan Al'rb. Dar Sadr. Byrwt. Madh «Wrth».

39. Mrwh, H. (1985). Drasat Nqdyh Fy Dw' Almnhj Alwaq'y. M'sst Alabhath. T1 Byrwt S422.

40. Mrwh, H. (D. T). Almwqf Althwry Fy Aladb Walabda'. Dwn Dar Nshr. S61.

41. Almsyry,'. (2007). Drasat Fy Alsh'r. Mktbh Alshrwq Aldwlyh. Tb'h 1. Snh S 287

42. Alnablsy, Sh. (D. T). Mjnwn Altrab. Alm'ssh Al'rbyh Lldrasat Walnshr. Byrwt. S601.

43. Abw Nzar, S. (1996). Alsywf. M'sst Al'nqa' Lltjdyd Walebda'. T3. Flstyn. S 83-8-8-8-12-32-40-37-40-64-6775-80.

44. Abw Nzar, S. (1997). Alshyl. M'sst Al'nqa' Lltjdyd Walabda'. T1 S32.

45. Abw Nzar, S. (1999). Lknh Wtny. T2. M'sst Al'nqa'. Ynayr. Ram Allh -Flstyn. S 7-9.

46. Alqysy, M. (1982). Aghany Alm'mwrh, Dar Alafq Aljdyd. T1. 'man S. 74.

47. Abw Zyd, Sh. (1995). Almsadr Altrathyh Fy Alsh'r Alflstyny. Rsalt Dktwrah Fy Aljam'h Alardnyh. S16.

48. Als'afyn, E. (1981). Mdrst Alehya' Waltrath. Dar Alandls. S 26.

49. S'wd, J. (1974). Alra'd. Dar Al'lm Llmlayyn. Byrwt. S 382.

50. Alsaygh, Y. (1978). Alsh'r Alhr Fy Al'raq Hta 'am 1958 Bghdad. Mtb't Rmzy. S 162.

51. Sfdy,M. (1970). Mqdmt Dywan Smyh Alqasm (Ala'mal Alsh'ryh Alkamlh). Dar Al'wdh. Byrwt. S. S. 
52. Smyr Nwfa, A. (1975). Mwjz Tarykt Alnzryat Aljmalyh. T'ryb: Basm Alsqar. Dar Alfaraby. Byrwt S466.

53. Alsyab, B. Akhbar Wqdaya. Mjlt Sh'r. Byrwt. Al'edd (3) Alsnh Alawla S111.

54. Tzyny, T. (D. T). Mn Altrath Ela Althwrh. Dar Abn Khldwn. Byrwt. S 279.

55. Alwly, Kh. (1956). Ara' Fy Alsh'r Walqsh. J1. Dar Alm'arf. Bghdad S19.

56. Yaghy, '. (1974). Fy Alnqd Alnzry. Aldar Al'rbyh Llnshr. 'man. S 65.

57. Yqtyn, S. (1992). Alrwayh Waltrath Alsrdy Mn Ajl W'y Jdyd Baltrath. Almrkz Althqafy Byrwt. S126.

Zayd 'shry, '. (1978). Astd'a' Alshkhsyat Altrathyh. Alshrkh Al'amh Llnshr Waltwzy'. Trabls. Lybya. S 52-41-27. 